UPPSALA UNIVERSITET
Working Paper 2006:17

Department of Economics

\title{
Mind the Gap? Estimating the Effects of Postponing Higher Education
}

Bertil Holmlund, Qian Liu and Oskar Nordström Skans 
Department of Economics

Uppsala University

P.O. Box 513

SE-751 20 Uppsala

Sweden

Fax: +4618471 1478
Working paper 2006:17

August 2006

ISSN 1653-0975

Mind the Gap? Estimating the Effects of Postponing Higher Education

Bertil Holmlund, Qian Liu and Oskar NordsRÖm Skans

Papers in the Working Paper Series are published on internet in PDF formats.

Download from http://www.nek.uu.se

or from S-WoPEC http://swopec.hhs.se/uunewp/ 


\title{
Mind the Gap? \\ Estimating the Effects of Postponing Higher Education ${ }^{\#}$ \\ by \\ Bertil Holmlund*, Qian Liu and Oskar Nordström Skans ${ }^{\dagger}$
}

This version: August 15, 2006

\begin{abstract}
This paper estimates the effects on earnings of "gap years" between high school and university enrollment. The effect is estimated by means of standard earnings functions augmented to account for gap years and a rich set of control variables using administrative Swedish data. We find that postponement of higher education is associated with a persistent and non-trivial earnings penalty. The main source of the persistent penalty appears to be the loss of work experience after studies. The reduction of lifetime earnings associated with two years postponement of higher education amounts to 40-50 percent of annual earnings at age 40 .
\end{abstract}

JEL-classification: I23, J24, J31.

Keywords: timing of education, schooling interruptions, returns to work experience.

\footnotetext{
\# We thank seminar participants at Uppsala University as well as Iida Häkkinen, Hessel Oosterbeek and Björn Öckert for helpful comments. Financial support from the Swedish Council for Working Life and Social Research (FAS) is gratefully acknowledged.

* Department of Economics, Uppsala University, Box 513, SE-751 20 Uppsala, SWEDEN. Bertil.Holmlund@nek.uu.se

$\S$ Department of Economics, Uppsala University, Box 513, SE-751 20 Uppsala, SWEDEN. Qian.Liu@nek.uu.se

† Institute for Labour Market Policy Evaluation (IFAU), Box 513, SE-751 20 Uppsala, SWEDEN

Oskar.Nordstrom_Skans@ifau.uu.se
} 


\section{Introduction}

Conventional human capital theory predicts that investment in formal education occurs early in the life cycle. Formal education should precede work, a result implied by models where individuals attempt to maximize their wealth. By specializing in schooling early in life, the period over which the returns to investment can be reaped is extended. Indeed, this time sequence of schooling followed by work is also what we observe as the typical real-world pattern.

However, this time sequencing does not hold universally. Some young people prefer to postpone the start of their university education one or several years whereas others take a break in the middle of their education. In British vocabulary, the phenomenon of taking a year's break between high school graduation and university is known as doing a "gap year". Anecdotal evidence reported in the media suggests that gap years are common in the UK, and possibly on the rise in the US. ${ }^{1}$ In Sweden, there also seems to be a popular perception that the prevalence of gap years is on the rise and the Danish "Welfare commission" reports that gap years in Denmark are frequent and amounting to several years on average (Velfærds-kommissionen, 2005).

Should the existence, and possibly increasing prevalence, of gap years be a matter of concern? Some have argued that gap years are socially costly as they presumably reduce the number of years of work after university graduation. ${ }^{2}$ If the postponement of university education carries no positive productivity effects, this concern may be warranted. But there seems to be very little evidence about how one or two gap years after high school affect labor market outcomes after university graduation. The present study aims to fill some of this gap in knowledge. In particular, we will provide estimates of how gap years affect earnings after university. The policy relevance of the question is clear: if taking a year off is wasteful rather than productive, policies should make it more costly to postpone higher education.

A variety of reasons for gap years are conceivable. To fix ideas, we may distinguish between at least five types of gaps, viz. (i) gaps as investment in skills, (ii) gaps as leisure, (iii) gaps as

\footnotetext{
${ }^{1}$ The prevalence of school interruptions in the US is documented in Light (1995) and Monks (1997). Some data suggest that one-third of high school graduates interrupt their schooling before re-enrolling in college. In Britain, a thriving "gap year industry" has emerged which offers gap year ideas, gap year travel destinations, gap year jobs etcetera. A Google search on "gap year" returns over two million hits.

${ }^{2}$ See Landell et al (2000) for a discussion of the Swedish case and Velfærdskommissionen (2005) for an analysis of detours in the Danish education system.
} 
waiting for better educational opportunities, (iv) gaps as learning about ones preferences and/or ability, and (v) military service.

Investment activities during gap years can take the form of work that is relevant for future studies and/or the career subsequent to university graduation. This includes behavior that improves work related skills, such as learning punctuality and good work habits. It could also involve the acquirement of social skills and language skills; indeed, anecdotal evidence on gap years often identifies "traveling abroad" as an important element of the gap period. Needless to say, the borderline between investment in skills and consumption of leisure is fuzzy when investment involves traveling abroad.

Some models of optimal investment in human capital with endogenous labor supply and perfect capital markets do allow for the possibility of bunching leisure early in life (Blinder and Weiss, 1976). This requires high "impatience", and in particular that the subjective rate of time preference is sufficiently large relative to the rate of interest. This may perhaps be seen as an exotic possibility. However, one can argue that the "capacity” for some forms of leisure consumption may be age-dependent. For example, the absence of family commitments around age 20 may enhance the range of feasible leisure consumption alternatives (long-distance traveling being one example).

A gap year may also sometimes be described as an "involuntary" pause that is the result of a failure to get accepted at the preferred education. The search for educational opportunities, like job search, involves applications, waiting for offers, and acceptance decisions if offers appear. ${ }^{3}$ Failure to get an offer, or rejection of offers, means in practice that the student has to wait until the next year's application round. The waiting period can be used in various ways, including further education so as to improve the chance of getting an acceptable offer next year. In Sweden, high school graduates are offered a second chance: they can take part in special courses so as to improve their grade points or they can take new and more advanced high school courses.

Finally, one can also imagine that a gap year might be a useful response to uncertainty about preferences and/or ability. If you can't decide what you want to do in life, why not postpone the

\footnotetext{
${ }^{3}$ Comay et al (1973) formalize a sequential schooling decision problem with exogenous probabilities of advancing through a number of education levels. Heckman et al $(2003,2005)$ include elaborations and extensions of this approach. Altonji (1993) is a related contribution where education decisions under uncertainty are modeled.
} 
decision until tomorrow, or next year? Taking a gap year might be individually (and possibly socially) beneficial to the extent that it reduces uncertainty about preferences and/or ability and thereby also the risk of choosing the wrong track.

Our aim in this paper is to offer evidence on how delayed transitions to higher education affect subsequent earnings and lifetime earnings. We exploit rich Swedish register data with complete coverage of the population of interest, i.e., individuals who have started a university education. ${ }^{4}$ These data allow us to retrieve information about direct and delayed transitions to higher education. We merge the data with other registers that contain information on earnings and employment as well as a host of other variables.

The results suggest that gap years are associated with lower future earnings. Individuals in their 30s earn less, the more gap years they have taken. The earnings penalty gradually diminishes over time and has vanished around age 40. This pattern is a robust feature of the data and persists after controls for a vast number of personal characteristics, including detailed information about levels and fields of education as well as measures of high school performance. The main source of the earnings penalty associated with gap years is that the returns to post-university work experience are higher than the returns to gap years. Postponement of university education reduces time for post-university investment in skills and therefore entails lower earnings subsequent to university graduation. The discounted present value of foregone lifetime earnings associated with two gap years amounts to around 40-50 percent of annual earnings at age 40 .

The remainder of this paper is organized as follows. We begin in the next section with a brief review of related literature. Section 3 presents the data that we use and Section 4 gives a descriptive overview of how the timing of transitions to university education has evolved over recent decades. Section 5 discusses the empirical strategies and presents the results. Section 6 concludes.

\section{Related Literature}

Our paper is related to the vast literature on how the individual's work history affects subsequent earnings. Since Mincer (1974), it has become conventional to specify log earnings as a function of a quadratic in cumulative work experience (in addition to schooling and a few other

\footnotetext{
${ }^{4}$ By 'university' we mean universities as well as university colleges.
} 
variables). Although this specification has stood up reasonably well to some simple alternative functional forms, ${ }^{5}$ it is not well suited to deal with discontinuous labor force careers. The literature on the effects of (female) work interruptions, pioneered by Mincer and Polachek (1974), has seen a large number of specifications where the work history is characterized in substantial detail. A good example is Light and Ureta (1995), who include an array of variables that capture the timing and length of work spells over the career, a specification that is found to outperform Mincer's original specification. ${ }^{6}$ By and large, there is evidence that work interruptions are associated with wage penalties, but there is considerable variation in the magnitude of the estimated effects.

A smaller literature has focused on the returns to work while in school. Hotz et al (2002) is a recent contribution that also includes references to the previous literature on this topic. This literature has been mainly preoccupied with how work while in high school affects subsequent wages of (young) men. A number of studies based on US data have asserted that work while in school brings positive and long-lasting wage returns. One possible causal interpretation could be that early work experience produces useful human capital, such as good work habits etcetera. However, there is an issue as to whether the results are truly causal or reflect unobserved individual characteristics. Hotz et al (2002) find that previous estimates are dramatically diminished when controls for selection are introduced.

Most studies dealing with the earnings effects of combining education and work have dealt with high school education. There is at least one paper that focuses on how working while in university affects future labor market outcomes, namely Häkkinen (2006). She makes use of data from Finland and estimates a positive, albeit not long-lasting, effect of combining work and university studies.

It is often argued that the ability to learn is declining with age ("you can't teach an old dog new tricks”). It seems unlikely that this argument carries much weight as long as modest postponements of higher education are considered. In fact, there is at least some evidence that

\footnotetext{
${ }^{5}$ See Heckman and Polachek (1974). Heckman et al (2003) offer a more critical assessment.

${ }^{6}$ In addition to the references above, the literature on work interruptions and their effects on wages include, among many other contributions, Baum (2002), Corcoran and Duncan (1979), Mincer and Ofek (1982), Corcoran et al (1983) and Gronau (1988). Swedish evidence concerning the effects of work interruptions due to parental leave is given in Stafford and Sundström (1996) and Albrecht et al (1999). Nordström Skans and Lindqvist (2005) provide quasi-experimental estimates of the effects of career breaks by exploiting information from a Swedish labor market program that introduced subsidized work interruptions.
} 
academic performance is increasing in age. Smith and Naylor (2001) examine the determinants of degree performance among undergraduates at UK universities in 1993. They find that older students generally perform better than younger ones, controlling for a rich set of covariates.

There is a very small US literature on the effects of schooling interruptions that is most closely related to what we do in the present paper. Griliches (1980) uses NLS Young Men data with information on schooling interruptions and estimates wage equations based on data from 1970 . He finds no evidence that schooling interruptions have had any adverse effect on subsequent wage rates. Marcus (1984) uses the same data as Griliches but focuses on wage outcomes in 1973 and includes more elaborated specifications than those adopted by Griliches. The return to time spent as interrupter of schooling is found to be significantly lower than the return to potential work experience subsequent to completed schooling. Light (1995) uses longitudinal data from 1979 to 1989 based on NLSY, focusing on white males. The results vary by the individuals' completed education. Among individuals with 12 years of school, there are negligible wage differences between those with and without schooling interruptions. Among those with 16 years of schooling, however, there is evidence of a wage penalty associated with schooling interruptions. Finally, Monks (1997) extends Light's analysis by using NLSY from 1970 to 1993 and by including women and minorities in addition to white males. The main result is that those who complete college at a later age receive a smaller initial increase in the wage than those who have completed college earlier in life.

In summary, there is overwhelming evidence that life cycle events concerning work and education are key determinants of individual earnings. However, only a handful of studies have addressed how labor market outcomes are affected by the timing of work and higher education. The results from these studies are mixed and their general applicability is uncertain. Our study sheds new light on how the timing of education affects wages, earnings and employment. In all likelihood, our Swedish register data on education are less plagued by measurement errors than the survey data used by previous researchers.

\section{The Data}

\subsection{Data Sources}

We study individuals with completed university education using the Swedish IFAU-database which combines data from various population-wide registers constructed by Statistics Sweden. 
We use register data on earnings, wages and employment as well as detailed data on university and pre-university education which we combine with census information on parents' education and socio-economic background.

Our data capture the year of each individual's first university enrollment from 1977 onwards and we have data on all high school graduations from 1985. We measure gap years in two ways. The first is the True Gap, denoted by $G$ and defined as the time between the year of high school graduation (YHSG) and the year of first university enrollment (YUE), i.e., $G=Y U E-Y H S G$. ${ }^{7}$ This measure requires information about high school graduations and since these only are available from 1985, we can only use cohorts born in 1966 or later. We focus most of our analysis on studying true gaps. Our second measure is Estimated Gap, Ge $=Y U E-19$, where 19 corresponds to the normal age of high school graduation. The point of using this alternative measure is that we are able to use more cohorts (from 1958) since it does not rely on high school graduation information. Therefore, we can evaluate more long run effects when we use estimated gaps. In cases where we can compare the two measures, they are highly correlated and produce very similar results. ${ }^{8}$ We are interested in the effects of the timing of studies among university educated individuals, who started their university studies adjacent to, but not necessarily directly following, high school graduation. To that end we focus on individuals taking up to four gapyears between high school and university enrollment.

Our last year of data coverage is 2002 and since wee primarily study outcomes at age 30 or later we can only use cohorts born in 1972 or earlier. Naturally, when outcomes are measured at a higher age, this restriction is put further back. In our main analysis, we restrict the analysis to those who complete their university education within seven years of study in order to ensure that all included individuals have completed their education by the time they turn 30. Completion of studies is defined as graduating with a degree that (formally) corresponds to at least three years of study.

Our main outcome variables are annual labor earnings and wages, both derived from the employment registers (RAMS) in the IFAU data base. The outcomes are available between 1985 and 2002. The employment variables we use from this dataset capture annual labor earnings and

\footnotetext{
${ }^{7}$ Multiple high school graduations are possible. However, over 95 percent of the graduates have just one graduation year, and we always use the first graduation year.

${ }^{8}$ A linear regression of $G$ against $G e$ yields a coefficient on $G e$ of 1.05 with R-square equal to 0.99 .
} 
employment status (as of November each year). ${ }^{9}$ We use the number of years an individual is employed to calculate work experience before, during and after university studies.

We construct a measure of wages as an alternative outcome variable. Data include information on the tax-records filed by each employer and from these records we can characterize each employer-employee relationship during a calendar year. We use two pieces of information, where the first piece contains the first and last month of an employment spell with an employer during the year. The second piece is information on the annual wage bill paid to the individual during this spell. We calculate wages by dividing the wage bill paid during an employment spell with the number of months the spell lasted. We keep spells with a wage that exceeds 75 percent of a minimum wage and that cover November. ${ }^{10}$ We also use at most one spell per individual (preference to the highest wage). Thus, we receive a wage measure that is corrected for the number of months of employment, but not for working hours. This procedure follows Nordström Skans et al (2006), who show that the derived wage distribution mimics the true wage distribution well.

In order to capture joint determinants of gaps and outcomes we rely on the inclusion of observed covariates. Our perhaps most important variable is a "field fixed effect" capturing the interaction between the formal length of the education (such as bachelor, master or doctoral) and direction of study for the degree. ${ }^{11}$ This leaves us with around 450 different possible field dummies. This allows us to restrict the analysis to comparisons within professions such as "math/science teachers”, “medical doctors specialized in radiology”, and "bachelors of economics” instead of pooling all of these together. Furthermore, we use data from RAMS on year of birth, gender, county of residence the first time the individual is observed, and immigrant status. When studying true gaps, we also control for the grade point average (GPA) at high school ${ }^{12}$ and the length of the high school education (2 or 3 years). ${ }^{13}$

\footnotetext{
${ }^{9}$ Labor income includes all incomes paid by the employer that are subject to social security fees and payroll taxes.

${ }^{10}$ The minimum wage is defined by wages for municipality-employed janitors. That all spells are required to cover November follows Statistics Sweden's definition.

${ }^{11}$ Measured at the most detailed level of the "SUN 2000"-coding system.

${ }^{12}$ Grades were at the time set on a scale from 1 to 5, and population GPA should have an overall normal distribution with mean 3 and standard deviation 1.

${ }^{13}$ During the time of study, Swedish high school education was divided into short (two years) mostly vocational programs and long (three years or - rarely - four years) academic programs. We include individuals with two or three year high school education.
} 
Our final data source is the 1990 national census from which we derive information on parents' socioeconomic and educational backgrounds. There are 11 different socioeconomic groups capturing whether the parent is employee or self-employed, skilled or unskilled, manual or nonmanual, working in manufacturing or in services etcetera. For parents' educational background, we have three categories, viz. less than high school, high school and university. In a sensitivity analysis we use sibling fixed effects defined from having the same biological mother. This analysis does however reduce the sample size dramatically.

Table 1 shows the years that define our sample. A more detailed description is provided in the appendix (Figure A1). Computation of estimated gap years requires only information on the year of university enrollment. The members of the first cohort we study are born 1958 and are thus estimated to graduate from high school in 1977. The last year of our observation window is 2002. Labor market outcomes in 2002 will thus involve persons aged 30 to 44, corresponding to birth cohorts from 1972 back to 1958.

Table 1. Years of importance for the data construction.

\begin{tabular}{l|l|l|l|l|l|l}
\hline 1958 & 1966 & 1972 & 1977 & 1985 & 1990 & 2002 \\
\hline $\begin{array}{l}\text { First included } \\
\text { birth cohort. } \\
\begin{array}{l}\text { Age 19 in } \\
1977 .)\end{array}\end{array}$ & $\begin{array}{l}\text { First birth } \\
\text { cohort with } \\
\text { high school } \\
\text { information. } \\
\text { (Age 19 in } \\
\text { 1985.) }\end{array}$ & $\begin{array}{l}\text { Last included } \\
\text { cohort. } \\
\text { (Age 30 in } \\
\text { 2002.) }\end{array}$ & $\begin{array}{l}\text { Start of } \\
\text { register on } \\
\text { first university } \\
\text { enrollment }\end{array}$ & $\begin{array}{l}\begin{array}{l}\text { Start of register } \\
\text { on high school } \\
\text { information. }\end{array} \\
\text { Start of register } \\
\text { on outcomes. }\end{array}$ & $\begin{array}{l}\text { Year of } \\
\text { measurement } \\
\text { of family } \\
\text { background. }\end{array}$ & $\begin{array}{l}\text { Last year of } \\
\text { measuring } \\
\text { outcomes. }\end{array}$ \\
\hline
\end{tabular}

Table 2 shows how the resulting samples are affected by various restrictions. A large fraction of observations are lost by our exclusion of individuals with gaps greater than four years, especially for the age 35 sample. The reason for this restriction, which admittedly is somewhat arbitrary, is that we wish to focus on what may be deemed as "normal” gap periods, i.e., gaps that may typically be part of the young student's career plan. Adult education has become increasingly common in Sweden, but we conjecture that it is typically driven by other forces than those determining educational decisions among youths. As mentioned, we also require that the individuals have graduated within 7 years of study. This restriction, which allows us to analyze post university outcomes from age 30 and beyond, implies a further reduction of the sample at age $35 .{ }^{14}$ We examine the robustness of our results to both the length of the gaps and to the

\footnotetext{
${ }^{14}$ A detailed description of pathways through Swedish university education is given in Statistics Sweden (2003).
} 
restriction on graduation within 7 years and show that none of these restrictions are driving our results.

An additional restriction kicks in when we run earnings regressions with log earnings as the dependent variable. However, the overwhelming majority the university graduates that we consider have positive earnings so this restriction does not cause much further reduction in the number of observations. When studying wages, samples are reduced further (not shown in Table 2).

Table 2. Number of observations for subgroups and after imposed restrictions.

\begin{tabular}{|c|c|c|c|c|c|c|}
\hline $\begin{array}{l}\text { Univ. educ. } \\
\text { individuals } \\
\text { at age of } \\
\text { outcome } \\
\text { (30 or } 35 \text { ) }\end{array}$ & $\begin{array}{l}\text { Information } \\
\text { about year } \\
\text { of first } \\
\text { registration }\end{array}$ & $\begin{array}{l}\text { High school } \\
\text { information } \\
\text { (only } G \text { ) }\end{array}$ & $\begin{array}{l}\text { High school } \\
\text { graduation at } \\
\text { age } 20 \text { the } \\
\text { latest } \\
\text { (only } G \text { ) }\end{array}$ & $\begin{array}{c}\text { Gaps between } \\
0 \text { and } 4 \text { years }\end{array}$ & $\begin{array}{l}\text { 3-7 years } \\
\text { between first } \\
\text { registration } \\
\text { and univ. } \\
\text { graduation }\end{array}$ & $\begin{array}{l}\text { Resident } \\
\text { and positive } \\
\text { earnings at } \\
\text { age of } \\
\text { outcome }\end{array}$ \\
\hline
\end{tabular}

\begin{tabular}{|c|c|c|c|c|c|c|c|}
\hline $\begin{array}{l}G \text { at age } 30 \\
\text { Cohorts: } 1966- \\
1972\end{array}$ & 133,431 & 121,189 & 108,998 & 106,337 & 91,146 & 73,558 & 70,899 \\
\hline $\begin{array}{l}G \text { at age } 35 \\
\text { Cohorts: } 1966- \\
1967\end{array}$ & 44,535 & 38,676 & 30,850 & 30,170 & 23,157 & 15,812 & 15,209 \\
\hline $\begin{array}{l}\text { Ge at age } 30 \\
\text { Cohorts: } 1958- \\
1972\end{array}$ & 233,552 & 204,988 & & & 169,369 & 136,467 & 131,281 \\
\hline $\begin{array}{l}\text { Ge at age } 35 \\
\text { Cohorts: } 1958- \\
1967\end{array}$ & 172,955 & 142,688 & & & 103,092 & 71,690 & 68,833 \\
\hline
\end{tabular}

\section{University Enrollment and Gap Years}

University enrollment has risen substantially in Sweden since the early 1990s. The number of university entrants amounted to 51000 in the academic year 1990/91 and had risen to 66000 in 1995/96; by 2003/04, the number had risen further to 83000 persons. ${ }^{15}$ Some of this development is accounted for by an increasing number of foreign students, but the major factor is a trend increase in transition rates from Swedish high schools to universities. We first examine

\footnotetext{
${ }^{15}$ These numbers (from Statistics Sweden) refer to persons who are registered for the first time at any Swedish university or university college.
} 
how direct and delayed transition rates from high school to university have evolved over time. This is followed by an inspection of the distribution of gap years among university entrants.

\subsection{Direct and Delayed Transitions to University}

High school graduation typically occurs in May or June and university enrollment can take place earliest during fall or spring the following academic year. We define a “direct transition” as a transition that takes place within one year; delayed transitions are thus transitions that take place after two or more years. ${ }^{16}$ Direct transitions correspond to true gaps of zero or one years. Figure 1 shows the development since the late 1980s.

Figure 1. Direct and delayed transitions to university, 1989-2003, percent.

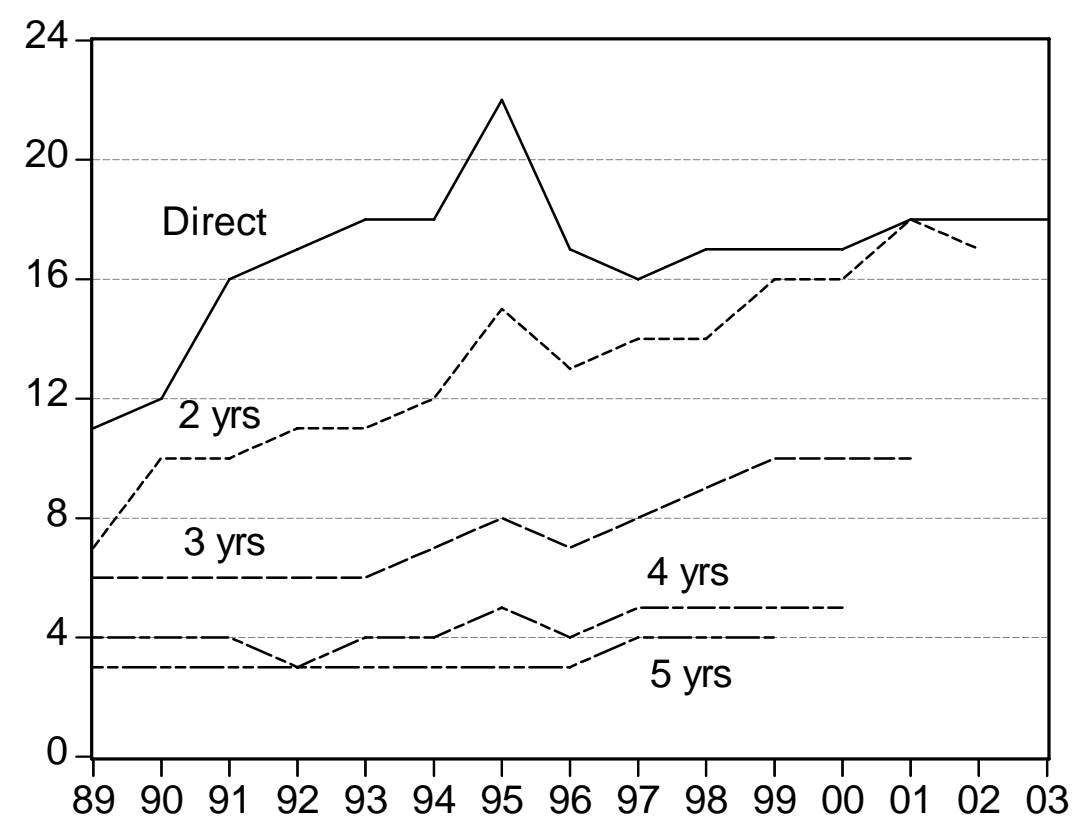

Notes: Direct transition is defined as a transition within one year after high school graduation. Graduation during $1988 / 89$ is labeled $89,1989 / 90$ is labeled 90 , etc. The transition rate for 1994/95 is affected by organizational changes of high school education.

Source: Statistics Sweden (UF 36 SM 0201, UF 36 SM 0401, SCB:s website).

There are marked trend increases in direct as well as two-year transition rates. The two-year transition rate has doubled since the late 1980s and by the turn of the century it has reached the same level as the direct transition rate. The fraction of a cohort of high school graduates who have enrolled at the university after five years was 30 percent in the late 1980s and had increased

\footnotetext{
${ }^{16}$ These transition rates are published by Statistics Sweden (Statistical Reports, series on the transition from upper secondary school to higher education) and originate from the same primary data sources as we use in most of the paper.
} 
to over 50 percent by the late 1990s. The data also reveal marked gender differences in transition rates (not shown), with women having higher direct as well as delayed transition rates. These gender gaps in transition rates have widened since the late 1980s.

\subsection{The Evolution of Gap Years}

Let us now turn to the evolution of gap years in our (unrestricted) data set. Figure 2 shows the distribution of estimated gap years among university entrants over the period 1977-2002. There is a marked increase in the 0-1 category in the early 1990s, a development that is reversed during the second half of the decade. This pattern is broadly consistent with the evolution of direct transition rates over the period; cf. Figure 1. Roughly speaking, the sharp increase in enrollment is largely driven by direct transitions in the early 1990s, and to a more significant degree by delayed transitions in the late 1990s.

Figure 2. The distribution of estimated gap years among university entrants 1977-2002, percent.

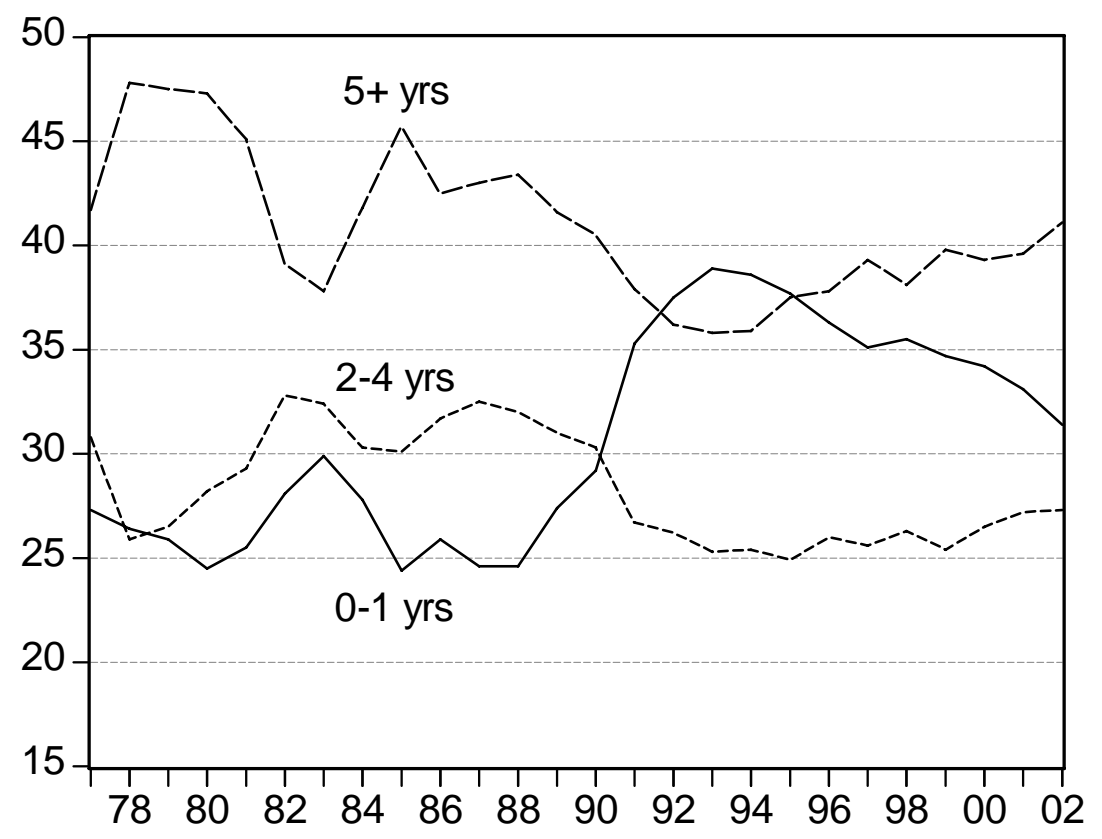

In Figures 3 and 4, we plot the mean and median estimated gap by first year of university enrollment over the period 1977-2002. ${ }^{17}$ The mean estimated gap over this period is around 6 years, whereas the median gap is 3 years. The large difference between the mean and the median reflects a highly skewed distribution. We also notice that women generally have longer gaps than men.

\footnotetext{
${ }^{17}$ We do not plot true gaps due to the lack of information on year of high school graduation before 1985.
} 
Figure 3. The evolution of male estimated gap years, mean (solid) and median (dashed), 1977-2002.

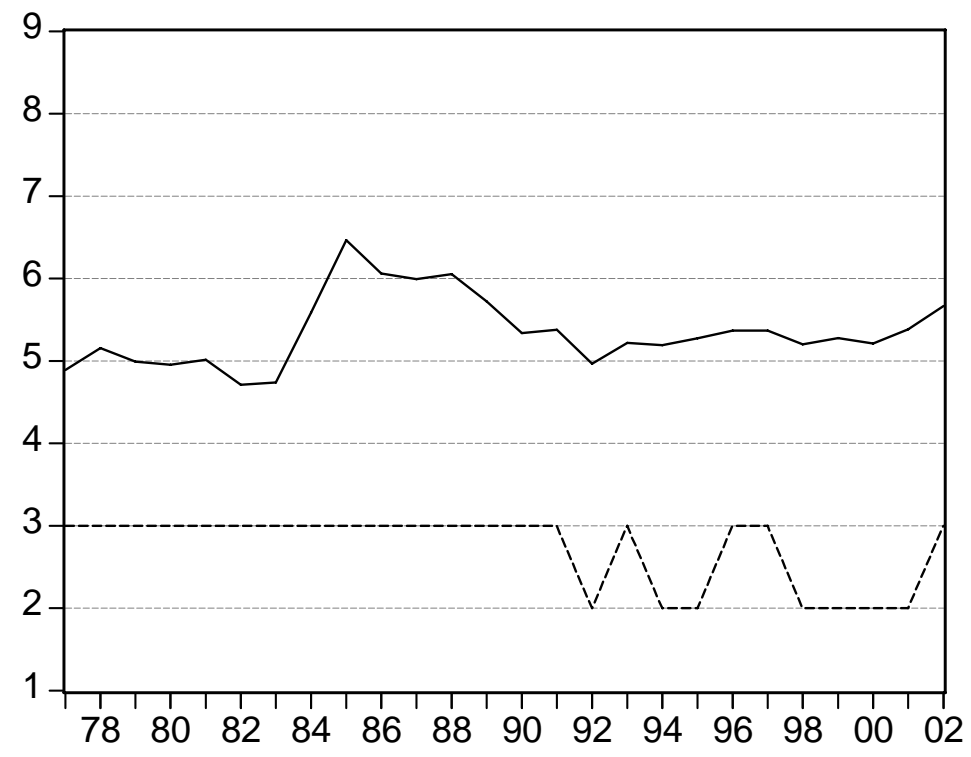

Figure 4. The evolution of female estimated gap years, mean (solid) and median (dashed), 1977-2002.

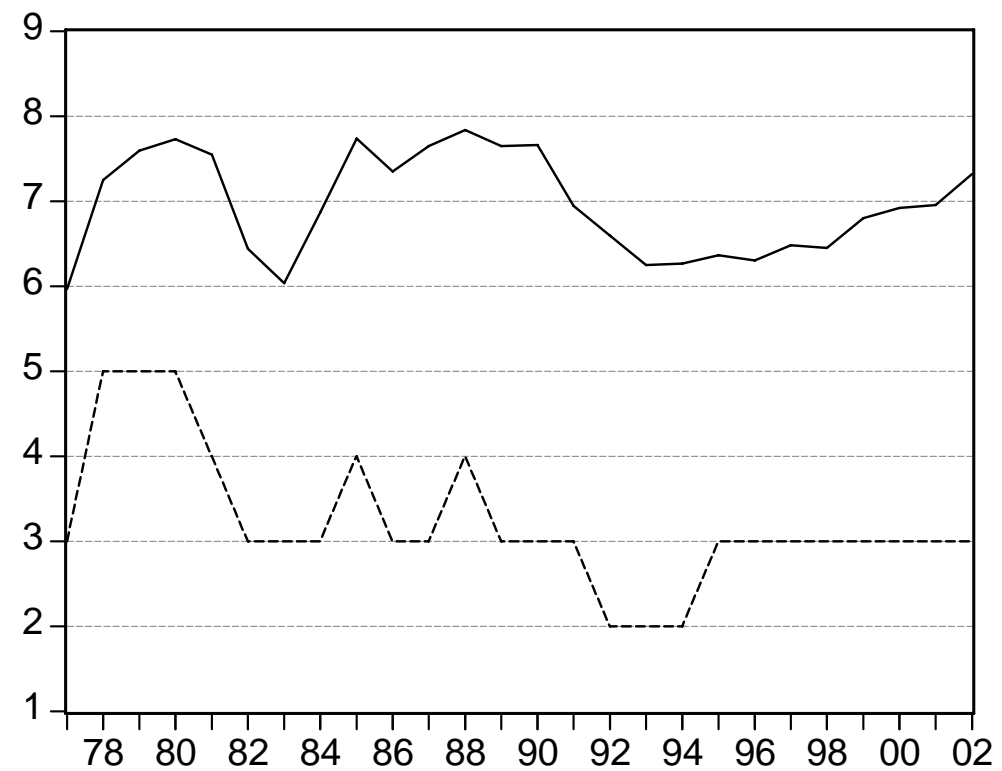

All in all, it is clear that gap years between high school and university are common. However, the data do not speak loudly in favor of the view that the prevalence of gap years has increased over time. As Figure 2 makes clear, the fraction of university entrants with long gaps has fallen since the late 1970s. Moreover, the fraction with zero or short gaps has increased over the 1990s. 


\subsection{Who are Doing Gap Years?}

We now turn to descriptive regressions aimed at documenting individual characteristics that correlate with gap behavior. We estimate a linear probability model for taking more than one gap year, with and without controls for field of education (FE). Each FE-category is a unique combination of the level (undergraduate or graduate) and the field of education. We also show results for a linear model with $G$ as dependent variable, also with and without FE-controls. The results are shown in Table 3.

A brief summary of the results runs as follows. Women are less likely than men to take gap years, a pattern that differs from what we have seen in the raw data. Immigrants from non-Nordic countries are also less likely to take gap years and the same holds for students with higher GPA's. Students with two-year high school education are more prone (relative to those with three years) to take gap years; this is as should be expected since they may need a gap year to qualify for some university educations. The effects of parents' education are not strong and systematic. ${ }^{18}$ Moreover, the results do not seem to be much affected by whether or not the FEcontrols are included.

One message to take away from Table 3 is that high school performance matters: the stronger performance in high school (as measured by GPA), the less likely to take gap years. This is as expected, since strong high school credentials imply generally higher chances of being accepted in any university education. One motive for gap years - waiting for better educational opportunities - is largely irrelevant for the top students.

An important issue that arises when attempting to estimate the effects of gap years is whether those are correlated with omitted individual characteristics (“ability”). If high ability students are much more likely to eschew gap years, the estimated gap effects may turn negative simply for omitted variable reasons. ${ }^{19}$ Our data do not make it possible to fully resolve this issue, but we will argue that the problem is unlikely to be severe since the results are robust to changes in observable characteristics. For example, the results remain essentially intact irrespectively of whether or not high school information is included.

\footnotetext{
${ }^{18}$ The results are virtually identical if parents' socioeconomic class is excluded.

${ }^{19}$ Interestingly, however, Griliches (1980) reports that individuals with schooling interruptions in his US sample have higher IQ's and come from more affluent backgrounds.
} 
Table 3. Who are doing gap years?

\begin{tabular}{|c|c|c|c|c|}
\hline \multirow[b]{2}{*}{ Female } & \multicolumn{2}{|c|}{$\begin{array}{c}\text { Linear probability model } \\
\text { Prob }(G>1)\end{array}$} & \multicolumn{2}{|c|}{$\begin{array}{l}\text { Linear model with } G \\
\text { as dependent variable }\end{array}$} \\
\hline & $\begin{array}{c}-0.035 \\
(0.003)^{* *}\end{array}$ & $\begin{array}{c}-0.073 \\
(0.003) * *\end{array}$ & $\begin{array}{c}-0.238 \\
(0.009)^{* *}\end{array}$ & $\begin{array}{c}-0.276 \\
(0.010)^{* *}\end{array}$ \\
\hline Born in the Nordic Countries & $\begin{array}{l}-0.019 \\
(0.019)\end{array}$ & $\begin{array}{l}-0.024 \\
(0.019)\end{array}$ & $\begin{array}{c}0.01 \\
(0.058)\end{array}$ & $\begin{array}{c}0.001 \\
(0.052)\end{array}$ \\
\hline $\begin{array}{l}\text { Born in Western Europe or } \\
\text { North America }\end{array}$ & $\begin{array}{c}-0.054 \\
(0.025)^{*}\end{array}$ & $\begin{array}{l}-0.052 \\
(0.023)^{*}\end{array}$ & $\begin{array}{c}-0.192 \\
(0.066)^{* *}\end{array}$ & $\begin{array}{c}-0.191 \\
(0.064)^{* *}\end{array}$ \\
\hline Other Immigrants & $\begin{array}{c}-0.086 \\
(0.013)^{* *}\end{array}$ & $\begin{array}{c}-0.082 \\
(0.012)^{* *}\end{array}$ & $\begin{array}{c}-0.301 \\
(0.036)^{* *}\end{array}$ & $\begin{array}{c}-0.287 \\
(0.034)^{* *}\end{array}$ \\
\hline 2-year High School & $\begin{array}{c}0.050 \\
(0.002)^{* *}\end{array}$ & $\begin{array}{c}0.052 \\
(0.003)^{* *}\end{array}$ & $\begin{array}{c}0.342 \\
(0.009)^{* *}\end{array}$ & $\begin{array}{c}0.367 \\
(0.008)^{* *}\end{array}$ \\
\hline GPA & $\begin{array}{c}-0.188 \\
(0.003)^{* *}\end{array}$ & $\begin{array}{c}-0.179 \\
(0.003)^{* *}\end{array}$ & $\begin{array}{c}-0.857 \\
(0.008)^{* *}\end{array}$ & $\begin{array}{c}-0.832 \\
(0.009)^{* *}\end{array}$ \\
\hline $\begin{array}{l}\text { Father's Education } \\
\text { Less than High School }\end{array}$ & $\begin{array}{l}-0.007 \\
(0.005)\end{array}$ & $\begin{array}{l}-0.005 \\
(0.005)\end{array}$ & $\begin{array}{c}-0.029 \\
(0.014)^{*}\end{array}$ & $\begin{array}{c}-0.032 \\
(0.013)^{*}\end{array}$ \\
\hline University & $\begin{array}{l}-0.004 \\
(0.005)\end{array}$ & $\begin{array}{l}-0.005 \\
(0.005)\end{array}$ & $\begin{array}{c}-0.082 \\
(0.015)^{* *}\end{array}$ & $\begin{array}{c}-0.088 \\
(0.014)^{* *}\end{array}$ \\
\hline $\begin{array}{l}\text { Mother's Education } \\
\text { Less than High School }\end{array}$ & $\begin{array}{c}0.001 \\
(0.004)\end{array}$ & $\begin{array}{c}0.001 \\
(0.004)\end{array}$ & $\begin{array}{l}-0.012 \\
(0.013)\end{array}$ & $\begin{array}{l}-0.015 \\
(0.012)\end{array}$ \\
\hline University & $\begin{array}{c}0.013 \\
(0.005)^{*}\end{array}$ & $\begin{array}{c}0.009 \\
(0.005)\end{array}$ & $\begin{array}{l}-0.012 \\
(0.015)\end{array}$ & $\begin{array}{l}-0.024 \\
(0.014)\end{array}$ \\
\hline $\begin{array}{l}\text { Observations } \\
\text { R2 } \\
\text { FE / \# FE }\end{array}$ & $\begin{array}{l}73,558 \\
0.07 \\
\text { No }\end{array}$ & $\begin{array}{l}73,558 \\
0.08 \\
452\end{array}$ & $\begin{array}{l}73,558 \\
0.18 \\
\text { No }\end{array}$ & $\begin{array}{c}73,558 \\
0.18 \\
452\end{array}$ \\
\hline
\end{tabular}

Notes: Individuals born between 1966 and 1972 are included in the sample. The regressions also include 6 birth year dummies, 10 dummies respectively for the fathers' and mothers' socioeconomic classes and 24 dummies for county of residence at age 16. R2 with FE refers to R2 within. Robust standard errors in the parentheses.

* significant at 5\%; ** significant at $1 \%$. 


\section{Empirical Analysis of Gaps and Earnings}

We now turn to an empirical analysis of gaps, wages and labor income. We are ultimately interested in how the timing of university enrollment affects lifetime earnings. There is a presumption that postponement of enrollment is bound to reduce lifetime earnings since it most likely reduces time spent in the labor force subsequent to university graduation. However, the validity of the presumption depends, inter alia, on the extent to which gap years involve productive labor market activities; if they do, the associated frontloading of earnings may conceivably increase the present discounted value of lifetime earnings. The earnings' effects of gap years depend also on the extent to which they bring about on-the-job training that carries a return in terms of earnings subsequent to university graduation. Finally, the earnings' effects of gap years hinge crucially on the value of post-university labor market experience relative to the value of the gap experience.

\section{$\underline{5.1 \text { Gap Years and Subsequent Earnings }}$}

Estimation of the returns to gap years raises all the usual problems encountered in the huge literature on returns to schooling (and the somewhat smaller literature on returns to experience). Griliches (1977) contains an early discussion of some of the key issues involved; Card (1999) provides a recent survey. One potential problem is that gaps, like levels of schooling, are endogenously chosen by individuals, at least to some degree. A related problem is caused by the presence of omitted variables that affect education decisions as well as earnings. Measurement errors in schooling and work experience raise additional problems (although our data on education should be of high quality). However, it is noteworthy that a central message from the literature on the returns to schooling is that "the average (or average marginal) return to education is not much below the estimate that emerges from a standard human capital earnings function fit by OLS”. (Card, 1999, p 1802.) Our analysis relies on OLS estimates on cross section data, although with unusually detailed control variables for the field of education.

Let $y_{i, j}$ denote individual $i$ 's annual earnings, where subscript $j$ denotes the age group. We estimate cross-sectional earnings equations at different ages, explaining earnings by a set of covariates $(Z)$ and measures of gap years:

$$
\ln y_{i, j}=\alpha_{j}+Z_{i, j} \beta_{j}+\gamma_{j} G_{i, j}+\varepsilon_{i, j}
$$


The set of control variables includes a gender dummy, ${ }^{20}$ dummies for immigrant status, a dummy variable of having two-year high school (instead of three years), GPA score, 10 dummy variables for father's (mother's) socioeconomic group, father's (mother’s) educational background, 24 dummies for county of residence at age 16, and dummy variables for year of birth. Most of the specifications also control for field of education. The specification of the equation for wages $\left(w_{i, j}\right)$ is analogous.

We start our analysis at age 30, the first year when all included individuals have graduated from university. This is also the year when we have the most observations since we are able to include the cohorts 1966-1972 (when studying true gaps). Table 4 displays the estimates of the gap year effects. We start by estimating a model without the field of education effects (column 1). The estimates clearly suggest a negative effect of taking a gap year. We add controls for field and duration (of university education) in columns 2 to 3 . The effects are not influenced much by these variables. The linear estimate implies that the earnings penalty is around 3 percent per gap year. In column (4) we relax the linear restriction for the gap effect and the evidence suggests a monotonic relationship between gap length and the earnings penalty. In column (5) we find a similar pattern for wages as we did for earnings. Whereas the earnings effect of an additional gap year appears to be increasing with the number of gap years, the wage effect appears almost strictly linear. The effects on employment probabilities are negative but less clearly monotonic (column 6).

The estimates in Table 4 imply that individuals with the same actual length, formal level and field of education earn less at age 30 if they had started their university studies later. Given that the durations (and age) are the same, potential experience is also equal, yet their earnings differ systematically. This suggests that the timing of education is indeed important, at least early in the post-education career.

\footnotetext{
${ }^{20}$ The results for men and women are similar and we have therefore pooled the data across gender.
} 
Table 4. Gaps and labor market outcomes at age 30, cohorts born 1967-1972.

\begin{tabular}{|c|c|c|c|c|c|c|}
\hline & \multicolumn{4}{|c|}{ Dependent variable: log annual earnings } & \multirow{2}{*}{\begin{tabular}{|r|}
$\begin{array}{l}\text { Dep. var. } \\
\text { log wage }\end{array}$ \\
$(5)$ \\
\end{tabular}} & \multirow{2}{*}{$\begin{array}{l}\text { Dep. var. } \\
\text { Prob(employment) } \\
(6)\end{array}$} \\
\hline & $(1)$ & $(2)$ & (3) & $(4)$ & & \\
\hline $\bar{G}$ & $\begin{array}{c}-0.036 \\
(0.003)^{* *}\end{array}$ & $\begin{array}{c}-0.024 \\
(0.003)^{* *}\end{array}$ & $\begin{array}{c}-0.029 \\
(0.003)^{* *}\end{array}$ & & & \\
\hline $\begin{array}{c}\text { Duration of } \\
\text { studies }\end{array}$ & & & $\begin{array}{c}-0.034 \\
(0.003)^{* *}\end{array}$ & $\begin{array}{c}-0.034 \\
(0.003)^{* *}\end{array}$ & $\begin{array}{c}-0.023 \\
(0.001)^{* *}\end{array}$ & $\begin{array}{c}-0.012 \\
(0.001)^{* *}\end{array}$ \\
\hline$G=1$ & & & & $\begin{array}{l}-0.016 \\
(0.009)\end{array}$ & $\begin{array}{c}-0.021 \\
(0.004)^{* *}\end{array}$ & $\begin{array}{c}-0.005 \\
(0.003)^{*}\end{array}$ \\
\hline$G=2$ & & & & $\begin{array}{c}-0.034 \\
(0.009)^{* *}\end{array}$ & $\begin{array}{c}-0.040 \\
(0.004)^{* *}\end{array}$ & $\begin{array}{l}-0.004 \\
(0.003)\end{array}$ \\
\hline$G=3$ & & & & $\begin{array}{c}-0.071 \\
(0.011)^{* *}\end{array}$ & $\begin{array}{c}-0.066 \\
(0.004)^{* *}\end{array}$ & $\begin{array}{c}-0.008 \\
(0.003)^{* *}\end{array}$ \\
\hline$G=4$ & & & & $\begin{array}{c}-0.130 \\
(0.013)^{* *}\end{array}$ & $\begin{array}{c}-0.093 \\
(0.005)^{* *}\end{array}$ & $\begin{array}{c}-0.016 \\
(0.004)^{* *}\end{array}$ \\
\hline Observations & 70,899 & 70,899 & 70,899 & 70,899 & 57,900 & 73,558 \\
\hline R2 & 0.12 & 0.05 & 0.05 & 0.05 & 0.16 & 0.01 \\
\hline FE / \# FE & No & 450 & 450 & 450 & 427 & 452 \\
\hline
\end{tabular}

Note: Individuals born between 1966 and 1972 are included in the sample. The regressions include a gender dummy, dummies for immigrant status (Swedish born, Nordic, Western or Other), high school GPA, length of high school education, 6 birth year dummies, 10 dummies respectively for the fathers' and mothers' socioeconomic classes, 3 for the mothers' and fathers' education and 24 dummies for county of residence at age 16 (or in 1985, whichever comes first). R2 with FE refers to R2 within. Robust standard errors in the parentheses. * significant at 5\%; ** significant at $1 \%$.

\section{Robustness}

In Table 5 we show estimates when outcomes are measured at age 35 . We first use the same basic restrictions, meaning that the individuals should all have completed their university education at age 30. Thus, they all have had at least five years to establish themselves on the labor market. In order to study the outcomes at age 35 we need to focus on the cohorts born in 1966 or 1967 so the sample sizes are reduced. Therefore, and to save space, we focus on the linear effect of gap years. We see evidence of some convergence over time (the earnings effect is -0.021 at age 35 which should be compared to -0.029 at age 30 in Table 4), but the effects are still significant and negative for both earnings and wages at age $35 .^{21}$

\footnotetext{
${ }^{21}$ The same pattern of gradual convergence is also evident when following the cohorts 1966-67 over time.
} 
In Table 5 we also relax the restriction of 1-4 years of gaps without much change in estimates, neither for earnings nor for wages. We also show estimates where we remove the restriction of graduating within 7 years, again without much change in results. ${ }^{22}$ We perform both of these robustness checks for the age 35 model since the restrictions have a larger impact at higher ages (there is more possible variation in both duration and gaps; see also Table 2). The fact that the results are robust in these dimensions suggests that our conclusions are not driven by the sample creation strategy.

Table 5. Sensitivity checks at age 35 - models with and without restrictions on Gaps and Durations.

\begin{tabular}{|c|c|c|c|c|c|c|}
\hline & \multicolumn{3}{|c|}{ Earnings } & \multicolumn{3}{|c|}{ Wages } \\
\hline & (1) & (2) & (3) & (4) & (5) & (6) \\
\hline$G$ & -0.021 & -0.023 & -0.026 & -0.020 & -0.018 & -0.019 \\
\hline & $(0.006)^{* *}$ & $(0.003)^{* *}$ & $(0.003)^{* *}$ & $(0.003)^{* *}$ & $(0.001)^{* *}$ & $(0.001)^{* *}$ \\
\hline Duration & -0.034 & -0.024 & -0.021 & -0.023 & -0.019 & -0.016 \\
\hline of studies & $(0.007)^{* *}$ & $(0.006)^{* *}$ & $(0.003)^{* *}$ & $(0.003)^{* *}$ & $(0.003)^{* *}$ & $(0.001)^{* *}$ \\
\hline \multicolumn{7}{|l|}{ Restrictions } \\
\hline Gaps & $0-4$ & All & All & $0-4$ & All & All \\
\hline Duration & $3-7$ & $3-7$ & All & $3-7$ & $3-7$ & All \\
\hline Observations & 15,209 & 20,321 & 28,398 & 13,060 & 16,974 & 23,411 \\
\hline R2 & 0.08 & 0.07 & 0.06 & 0.13 & 0.12 & 0.11 \\
\hline \# FE & 181 & 406 & 506 & 174 & 380 & 480 \\
\hline
\end{tabular}

Note: The regressions include a gender dummy, dummies for immigrant status (Swedish born, Nordic, Western or Other), high school GPA, length of high school education, 6 birth year dummies, 10 dummies respectively for the fathers' and mothers' socioeconomic classes, 3 for the mothers' and fathers' education and 24 dummies for county of residence at age 16 (or in 1985, whichever comes first). Education information is taken at age 30 for columns (1) and (4) for consistency with Table 4 and at age 35 for columns (2), (3), (5) and (6). R2 refers to R2 within. Robust standard errors in the parentheses. * significant at $5 \%$; ** significant at $1 \%$.

It should be noted that our identification relies entirely on observed characteristics for a causal interpretation of the estimates. The reason is that, as when studying the returns to the level of education, good instruments are extremely hard to come by. Furthermore, it is even more difficult to think of instruments that affect the timing of education and not the probability of actually pursuing higher education, which will cause problems if there are heterogeneous returns to education. In passing, it is worth noting that the converse also holds even though it has been

\footnotetext{
${ }^{22}$ Since the Swedish university system allows individuals to register for single (sometimes part-time) courses and since we are unable to separate "real" studies from such occasional part-time courses for those that do not complete a degree, we retain the restriction of graduation throughout. This also allows us to control for the exact type of education.
} 
largely ignored in the literature - any instrument that affects participation is also likely to affect the timing, which may bias IV-based estimates of the returns to education.

With these caveats in mind we have explored three potential instruments that mainly should affect the timing although we can not exclude the possibility that the selection is affected as well. The three instruments are based on the timing of military service enrollment, the local labor market conditions at the time of high school graduation and an admissions reform. None of these attempts proved successful, however; the first stage estimates were far too imprecise to be informative.

Our most promising candidate instrument was a university enrollment reform performed in 198182 (see Högskoleverket, 1997). The explicit purpose of the reform was to reduce the number of gap years and it had several parts leading to this end. Most importantly, one third of slots were allocated specifically to those with less than three gap years, the possibilities of using work experience as a merit was reduced, and the possibility of using activities in non-governmental organizations as a merit was removed. The reform appears to have had an impact on the transition rates to university; the mean estimated gap (in the interval 0-4) dropped from 1.87 for the cohort born in 1961 to 1.62 for the cohort born in 1964 (the pattern is also visible in Figure 2 above). In order to use the reform as an instrument we adopted a regression discontinuity design. The instrument was defined as being born in cohorts 1963 or after and we assume that the underlying time and cohort pattern in real earnings follow a quadratic functional form (instead of using cohort dummies as previously). Under this assumption, cohorts born after 1963 should have shorter gaps but not different earnings for other reasons conditional on the quadratic term. The IV-estimates were considerably larger in absolute values $(-0.085)$ than the OLS-estimates, but quite imprecise (the standard errors were 0.06). A Hausman-test could not reject the consistency of the OLS estimates.

Given that none of our candidate instruments provided enough power for identification, and the intrinsic difficulties of finding truly reliable instruments for the timing of education, our overall conclusion is that we are restricted to relying on observable characteristics for identification. We made some further robustness checks by including more covariates in the model. Estimates are provided in Table A3 in the appendix. First, we used sibling fixed effects (based on the identity of the biological mother) instead of the observed family background variables. Second, we extended our model by interacting GPA with both the field of university education and the field 
of high school education (60 categories) simultaneously. The results are robust to both of these variations and we interpret this as evidence for the model being correctly specified both when it comes to controlling for family background, and when it comes to controlling for educational opportunities and (pre-university) scholastic abilities, lending support to our causal interpretation of the estimates.

\subsection{Gap-Effects over the Lifecycle}

So far we have restricted the analysis to wages and earnings at ages 30 and 35 . We now extend the focus to a large part of the life cycle by estimating the returns to gap years at each age where observations are available. That is, we run separate regressions based on eq. (1), letting age vary from 20 to $44 .^{23}$ By doing so, we can examine whether the convergence patterns discussed above are visible in the data. In order to include all these age groups, we need to use estimated gaps, i.e., imputed gaps based on the normal age at high school graduation. Although this forces us to drop high school information from the model, we can use all cohorts from 1958 and onwards and thus capture 25 years of the life cycle. ${ }^{24}$ We focus on earnings since we will use the same set-up to calculate the effects on real life time earnings in the following section.

Figure 5 displays the time pattern of gap estimates based on 25 separate regressions with log annual earnings as dependent variable. The patterns for men and women are very similar and the figure shows results from regressions where the data on men and women are pooled (and gender is accounted for by a dummy). In the early 20s, an additional gap year is associated with around 20 percent higher earnings. This is followed by a substantial dip in earnings around age 25, i.e., during the period of university enrollment when labor market activity is limited. After graduation there is a period of fairly slow catch up. The estimated effect at age 35 is 2.1 percent, exactly as in Table 5, where true gaps are used. Full convergence is eventually achieved in the early 40s; the estimated gap effects turn insignificant at age 42.

\footnotetext{
${ }^{23}$ Each regression is thus based on a different set of birth cohorts but the patterns are very similar between cohorts (see Figure A2 in the appendix). Controls for birth cohorts are included in each regression, as well as controls for field of education and other covariates discussed above (except high school information).

${ }^{24}$ We have also performed these exercises using the data on true gaps and with controls for GPA from high school. This can only be done for the age groups 20 to 36. The results are very similar to those displayed for estimated gaps.
} 
Figure 5. Estimated returns to gap years by age.

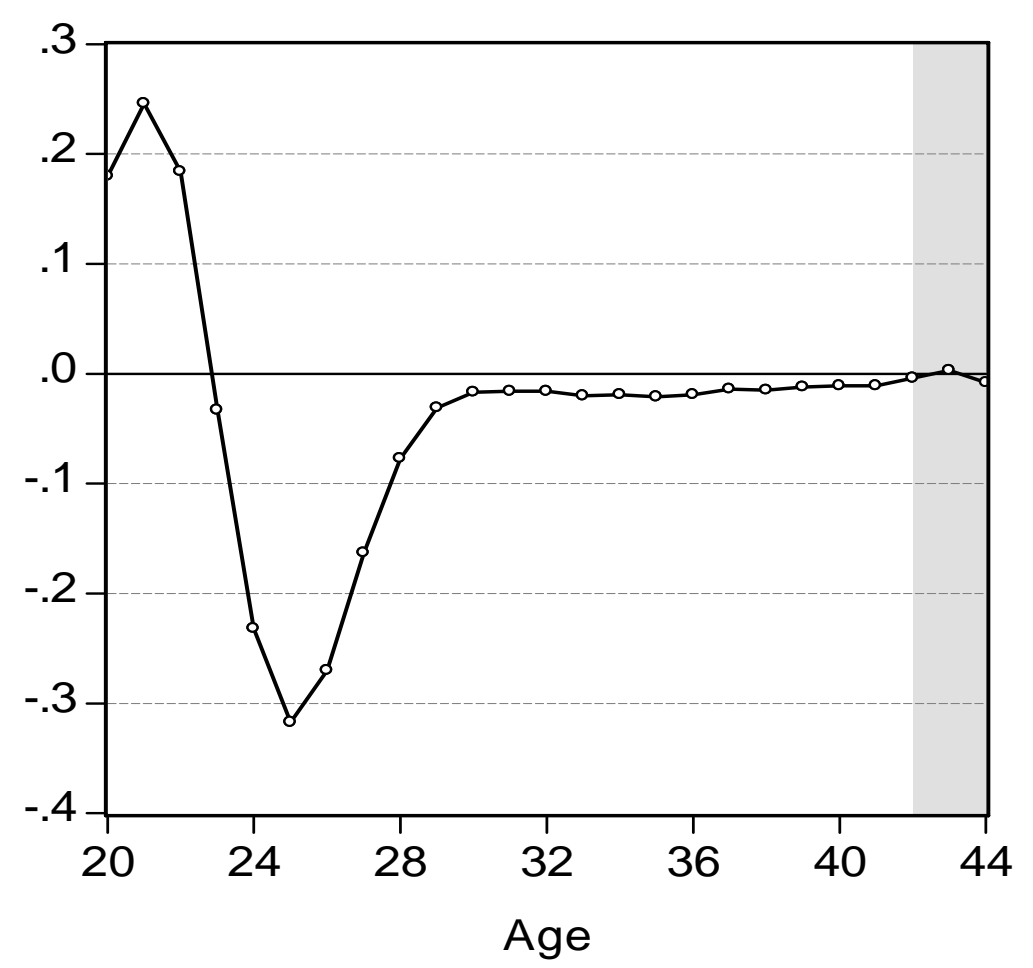

Note: The estimated gap effects on log annual earnings for ages 20-41 are all significantly different from zero, with absolute $t$-values ranging from 2.8 (at age 41) to 158.5 (at age 25). The shaded area highlights the three insignificant estimates (ages 42-44).

\subsection{Lifetime Earnings and the Costs of Gap Years}

We will now illustrate the implications for lifetime earnings of the patterns shown in Figure 5. Note that an effect on log earnings matters more for real lifetime earnings if it occurs when real earnings are high. We therefore need to transform the estimated effects on log earnings into effects on real earnings. Ideally we would do this by using the age-earnings profile for a single cohort. However, since our data does not contain such information, we choose to focus on the cohort born 1965 where earnings information is available for ages $20-37 .^{25}$ For this cohort and this age interval, we compute real earnings by deflating by the consumer price index. Real earnings during ages 38-44 for the 1965 cohort are imputed by using information on the evolution of real earnings for the 1958 cohort over the 38-44 age interval. The resulting series is thus intended to capture real earnings for the 1965 cohort from age 20 and up to age 44, remembering that the seven last years are imputed from data pertaining to the 1958 cohort. ${ }^{26}$ We

\footnotetext{
${ }^{25}$ Recall that we have information on at most 25 age groups (age 20-44), and 15 cohorts (born 1958-72). Observations on earnings are available for the years 1985-2002, which means that we do not have information on earnings for all 25 age groups for any single cohort.

${ }^{26}$ The earnings profile is "standardized" in the sense that it is based on estimated earnings equations of the form given by (1) above.
} 
assume that gaps have no effects beyond age 44, which is consistent with our estimates presented above.

Equipped with a "representative” earnings profile we can translate gap effects on log earnings into gap effects on real earnings in units of SEK. Let $\ln y_{r, j}$ denote real log earnings for age $j$ associated with our representative cohort, assuming no gaps. The corresponding profile with $G e=1$ is then given as $\ln y_{r, j}^{G}=\ln y_{r, j}+\gamma_{j}$, where $\gamma_{j}$ is the estimated gap parameter and $j \in\{20, \ldots, 44\}$ The key variable is the absolute difference between earnings associated with positive gaps and earnings associated with zero gaps, i.e.,

$$
\Delta y_{r, j}^{G}=\exp \left(\ln y_{r, j}+\gamma_{j} \cdot G e\right)-\exp \left(\ln y_{r, j}\right)
$$

where $G e \in\{1,2,3,4\}$. We have computed discounted present values of (5) for the 25 year period corresponding to ages 20-44, assuming a 4 percent discount rate and no earnings penalty after age 44. The results are given in Table 6 .

Table 6. The effects of gap years on the present value of lifetime earnings.

\begin{tabular}{l|c|c|c|c}
\hline & \multicolumn{2}{|c|}{ Men } & \multicolumn{2}{c}{ Women } \\
\hline & SEK & $\begin{array}{r}\text { Fraction of annual } \\
\text { earnings at age 40 }\end{array}$ & SEK & $\begin{array}{r}\text { Fraction of annual } \\
\text { earnings at age 40 }\end{array}$ \\
\hline$G e=1$ & -106700 & -0.21 & -92100 & -0.31 \\
$G e=2$ & -187800 & -0.37 & -157900 & -0.53 \\
$G e=3$ & -246800 & -0.49 & -200600 & -0.67 \\
$G e=4$ & -286100 & -0.57 & -221700 & -0.74 \\
\hline
\end{tabular}

Notes: The discount rate is set to 4 percent. It is assumed that no gap effects on earnings persist after age 44. The calculations pertain to the cohort born 1965 as described in the text. The returns to gap years are estimated separately for men and women.

The results suggest indicate non-trivial effects on lifetime earnings. Two gap years carry a lifetime loss in earnings that amount to 37 percent of annual earnings at age 40 for men; for women, the corresponding loss amounts to 53 percent. The reason that relative costs are larger for women is mainly that they have substantially lower earnings than men at age 40, partly reflecting much higher incidence of part time work. In absolute terms, the present value losses of 
gap years are somewhat higher for men. For $G e=2$, the present value loss (in 2002 prices) amounts to around 188000 SEK for men and 158000 SEK for women. ${ }^{27}$

The private costs of gap years will generally differ from those reported in Table 6 for mainly two reasons, viz. taxes and stipends. Progressive taxes reduce the net penalty of taking gap years analogous to the way they reduce the returns to higher education in general. Stipends, including grants and subsidized loans, may increase the incentives to study now rather than later, all else equal; postponement of studies involves also postponement of stipends and the more generous those are, the more costly the delay. However, the presence of stipends may also affect occupational choice by increasing the attractiveness of educations that have positive consumption values but perhaps modest effects on earnings.

\subsection{Gaps and the Returns to Work Experience}

How can we understand the persistent effects of gap years on earnings? Notice that we compare individuals with the same field, formal level and actual length of education (which means that they have the same amount of potential work experience), yet we find persistent effects on earnings even in the mid-30s. One possible explanation for this result is that gap years reduce the total amount of work experience and thereby the amount of human capital acquired on the job; another possibility is that gaps affect the timing of work experience (or "inactivity") in a way that is detrimental for earnings. To shed light on these issues, we proceed by estimating "time use equations" where individual time allocation after high school graduation is explained by the number of (true) gap years in addition to the covariates previously used. In a subsequent step we estimate earnings equations where our measures of time use are included as regressors. By doing so we can gain some understanding of how gap years affect earnings through the effects on time use after high school.

We focus on time use between high school graduation and age 35. This time span $(T)$ is treated as fixed and can be allocated to work experience $(X)$ or "inactivity" $(I)$, where the latter is defined as $I \equiv T-X .{ }^{28}$ Work experience is measured by using information about whether the individual is employed or not in November each year. This measure is thus binary for each year

\footnotetext{
${ }^{27}$ The exchange rates for July 2006 are 1 USD = 7.44 SEK, 1 EURO = 9.40 SEK.

${ }^{28} \mathrm{We}$ control for age at high school graduation in the estimations.
} 
but varies (in unit steps) depending on the number of years with work experience. ${ }^{29}$ Moreover, we distinguish between work experience before, during and after university studies. Since inactivity by construction is the mirror image of work experience we thus get three inactivity variables (before, during, after) corresponding to the three experience variables.

The results are presented in Table 7 . We see that one additional gap year is associated with 0.56 additional years of work before university, 0.05 additional years of work during university, and 0.75 fewer years of work after university. It is also associated with 0.44 years of extra inactivity before university, 0.19 fewer years of schooling without work, and 0.12 fewer years of inactivity after university. This sums, of course, to one year before start of university, and minus one year after start of university. Total work experience is reduced by 0.14 years. Since time is fixed it follows that total inactivity is increased by the same amount.

Table 7. Estimated effects of a gap year on activities between high school graduation and age 35, cohorts born 1966-67.

\begin{tabular}{l|c|c|c}
\hline & Experience $(X)$ & Inactivity $(T-X)$ & Total $(T)$ \\
\hline Before & $(1)$ & $(2)$ & $(3)$ \\
& 0.560 & 0.440 & 1 \\
During & $(0.004)^{* *}$ & $(0.004)^{* *}$ & -0.134 \\
& 0.052 & -0.185 & $(0.007)^{* *}$ \\
After & $(0.010)^{* *}$ & $(0.010)^{* *}$ & -0.866 \\
& -0.749 & -0.117 & $(0.007)^{* *}$ \\
\hline Total & $(0.014)^{* *}$ & $(0.012)^{* *}$ & 0 \\
\end{tabular}

Note: Inactivity is defined as not having worked. The model is estimated for 35 year olds using true gaps. The regressions include a gender dummy, dummies for immigrant status (Swedish born, Nordic, Western or Other), high school GPA, length of high school education, age at high school graduation, 6 birth year dummies, 10 dummies respectively for the fathers' and mothers' socioeconomic classes, 3 for the mothers' and fathers' education and 24 dummies for county of residence at age 16 (or in 1985, whichever comes first). Robust standard errors in the parentheses. * significant at $5 \%$; ** significant at $1 \%$.

So how can we make use of this information in order to understand the effects of a gap year? First of all we can note that a gap year reduces total work experience (thus increasing inactivity). Secondly, it places more of the experience before the studies, potentially reducing the value of the work experience. And thirdly, it changes the timing of inactivity by increasing inactivity before the studies and reducing it afterwards. To provide an interpretation of this pattern, we will explicitly incorporate actual work experience into our model. We allow for a quadratic of work

\footnotetext{
${ }^{29}$ Work experience is measured as the number of years with at least four hours of work performed in November. We have estimated models with stricter requirements, but the estimates are quantitatively similar. Results are available upon request.
} 
experience after university. We choose wages as the outcome variable since the returns to experience typically are discussed in those terms; results for annual earnings are available on request. The results are displayed in Table 8.

Table 8. Estimated effects of different activities on wages at age 35.

\begin{tabular}{|c|c|c|c|c|c|}
\hline & "Reduced & Years of & \multicolumn{2}{|c|}{ Timing of experience } & \multirow{2}{*}{$\begin{array}{l}\begin{array}{l}\text { Experience } \\
\text { and inactivity }\end{array} \\
\text { (5) }\end{array}$} \\
\hline & (1) & (2) & (3) & (4) & \\
\hline Gap year & $\begin{array}{c}-0.017 \\
(0.003)^{* *}\end{array}$ & & & & \\
\hline Total experience & & $\begin{array}{c}0.026 \\
(0.002)^{* *}\end{array}$ & & & \\
\hline Exp. before & & & $\begin{array}{c}0.010 \\
(0.004)^{*}\end{array}$ & $\begin{array}{c}0.008 \\
(0.004)\end{array}$ & $\begin{array}{c}-0.026 \\
(0.004)^{* *}\end{array}$ \\
\hline Exp. during & & & $\begin{array}{c}0.016 \\
(0.002)^{* *}\end{array}$ & $\begin{array}{c}0.015 \\
(0.002)^{* *}\end{array}$ & $\begin{array}{c}-0.020 \\
(0.003)^{* *}\end{array}$ \\
\hline Exp. after & & & $\begin{array}{c}0.035 \\
(0.002)^{* *}\end{array}$ & $\begin{array}{c}0.058 \\
(0.009)^{* *}\end{array}$ & Ref. \\
\hline (Exp. after) $)^{\wedge 2 / 100}$ & & & & $\begin{array}{c}-0.140 \\
(0.055)^{*}\end{array}$ & \\
\hline Inactivity before & & & & & $\begin{array}{c}-0.024 \\
(0.004) * *\end{array}$ \\
\hline Inactivity during & & & & & $\begin{array}{c}-0.036 \\
(0.003) * *\end{array}$ \\
\hline Inactivity after & & & & & $\begin{array}{c}-0.038 \\
(0.003)^{* *}\end{array}$ \\
\hline Observations & 13,077 & 13,077 & 13,077 & 13,077 & 13,077 \\
\hline R2 & 0.12 & 0.14 & 0.14 & 0.14 & 0.14 \\
\hline $\mathrm{FE}$ & 174 & 174 & 174 & 174 & 174 \\
\hline
\end{tabular}

Note: Inactivity is defined as not having worked. The model is estimated for 35 year olds using true gaps (Column 1). The regressions include a gender dummy, dummies for immigrant status (Swedish born, Nordic, Western or Other), high school GPA, length of high school education, age at high school graduation, 6 birth year dummies, 10 dummies respectively for the fathers' and mothers' socioeconomic classes, 3 for the mothers' and fathers' education and 24 dummies for county of residence at age 16 (or in 1985, whichever comes first). R2 refers to R2 within. Robust standard errors in the parentheses. * significant at 5\%; ** significant at $1 \%$.

The estimate in the first column, which can be loosely thought of as a reduced form, implies that an additional gap year results in a wage reduction by 1.7 percent at age 35 . An increase in years of work experience is associated with a wage increase by 2.6 percent, as shown in the second column. The third and fourth columns show that the timing of work experience also matters; the returns to work experience after graduation is much higher than the returns to work before or during the studies. Finally, we notice from the fifth column that the timing of inactivity also 
plays a role. Experience after university is chosen as the omitted time use category so an increase in inactivity, holding experience before and during university constant, must be accompanied by a decrease in experience after university. ${ }^{30}$ The estimates in the fifth column thus imply that a reduction in experience after university is more costly if it is driven by inactivity after university than by inactivity before university.

We now make use of the estimates in Table 7 and Table 8 to shed light on how gap years affect wages by influencing total work experience, the timing of work experience, and the timing of inactivity. If total experience is all that matters, we would get an expected effect of one more gap year by combining results from column (1) in Table 7 and column (2) in Table 8. In particular, since a gap year reduces total work experience we obtain the years of experience effect as the product of the returns to experience (0.026) and the decline in experience implied by a gap year (0.137). This effect amounts to a wage reduction of 0.4 percent. $^{31}$ Thus, the effect on total experience can only account for a small fraction of the total effect.

Let us next recognize the fact that a gap year affects not only the total amount of work experience but also its timing. We combine the estimates of experience effects before, during and after studies from column (2) in Table 7 and the estimates in Column (3) of Table 8 and obtain a timing of experience effect. This effect - which incorporates the effect on the amount of experience as well as its timing - amounts to a wage reduction of 2.0 percent. $^{32}$ Thus, the effect of timing in itself has a larger effect (-1.6 percent) than the effect through the amount of experience. Note that convergence over time can be understood by the negative quadratic term of post-university experience shown in Column (4).

Since the gap years also affect the timing of inactivity, we can use the "full” model of Column (5) of Table 8 with all the information in Table 7 to get a sense of how wages are affected by changes in the timing and amounts of both experience and inactivity. This timing of experience and inactivity effect implies a wage reduction of 1.6 percent. ${ }^{33}$ Note that this is not far from the estimated "reduced form" effect of a gap year of -1.7 percent, as given in the first column of Table 8.

\footnotetext{
${ }^{30}$ The six time use categories sum to a fixed number and can thus not all be included in the regression.

${ }^{31}$ This calculation as well as the subsequent ones in this section makes use of estimates with higher precision (more decimals) than those shown in Table 7 and Table 8.

32 The relevant calculations are as follows: $0.560 * 0.010+0.052 * 0.016-0.749 * 0.035 \approx-2.0 / 100$.

${ }^{33}$ This is obtained as follows: $-0.560 * 0.026-0.052 * 0.020-0.440 * 0.024+0.185 * 0.036+0.117 * 0.038 \approx-1.6 / 100$.
} 
The estimates, taken at face values, point to an interesting pattern. First, total experience matters since a gap year reduces the total amount of time spent working. Second, the timing of experience matters a lot: recall that a gap year substantially reduces experience after university

and that the returns to experience after university are much higher than the returns to other forms of experience. Third, the timing of inactivity matters as well. Inactivity before studies is much less harmful than inactivity after education. This last estimate is perhaps somewhat unusual but given that that we know that work interruptions reduce future wages above what can be explained by lost experience it is perhaps not so strange that the timing of inactivity matters.

\section{Concluding Remarks}

The transition from high school to higher education typically involves one or several gap years. Among Swedish university entrants around the turn of the century, some 25 percent had taken two to four gap years, and around 40 percent had more than five gap years. Scattered evidence from other countries suggests that the phenomenon of gap years is not unique to Sweden.

The paper has examined how postponement of higher education affects earnings subsequent to the completion of the studies. We have focused on "short” delays, i.e., delays up to four years but our estimates are robust both to variations in sample restrictions and inclusion of detailed controls for previous scholastic performance or sibling fixed effects. We find that such delays have negative effects on earnings and wages at ages 30 to 40 . One additional gap year is associated with 2 percent lower earnings and wages at age 35. This effect is non-trivial in the light of available estimates of the (marginal) returns to schooling in Sweden: according to recent estimates, the wage returns to an additional year of schooling amounts to 5 percent in the year 2000 (le Grand et al, 2001). The effects decline over time and disappear around age 40. We have also examined how gaps affect lifetime earnings and find that two gap years reduce the present value of lifetime earnings to the tune of 40-50 percent of annual earnings at age 40 .

We view the negative effects of gaps on earnings and wages as reflecting differential returns to experience before and after university studies. Our estimates suggest that the returns to postuniversity work experience are substantial whereas the returns to pre-university experience are negligible. However, there is clear evidence of declining marginal returns to post-university work experience, a feature that implies that the earnings profile associated with gap years tends to catch up to the no gap profile. A general lesson is that measures of work experience that do not account for the timing of the experience are imperfect indicators of human capital acquired 
on the job. Hence, the timing of education should be given a more explicit role in studies of the returns to education.

The analysis of this paper is incomplete as a guide to educational policy. There is a presumption, however, that the social costs to gap years exceed the private costs. The presence of substantial tax wedges is the main reason for this presumption. When designing systems of education finance, such as stipends and subsidized loans, it would therefore seem relevant to recognize how these systems affect the timing of higher education.

\section{References}

Albrecht, J, P-A Edin, M Sundström and S Vroman (1999), Career interruptions and subsequent earnings: A reexamination using Swedish data, Journal of Human Resources 34, 294-311.

Altonji, J (1993), The demand for and return to education when education outcomes are uncertain, Journal of Labor Economics 11, 48-83.

Baum, C (2002), The effects of work interruptions on women’s wages, Labour 16, 1-36.

Blinder, A and Y Weiss (1976), Human capital and labor supply: A synthesis, Journal of Political Economy 84, 449-472.

Comay, Y, A Melnik and M Pollatschek (1973), The option value of education and the optimal path for investments in human capital, International Economic Review 14, 421-435.

Corcoran, M and G Duncan (1979), Work history, labor force attachment, and earnings differences between the sexes, Journal of Human Resources 14, 3-20.

Corcoran, M, G Duncan, and M Ponza (1983), A longitudinal analysis of white women’s wages, Journal of Human Resources 18, 497-520.

Griliches, Z (1980), Schooling interruption, work while in school and the returns from schooling, Scandinavian Journal of Economics 80, 294-303.

Gronau, R (1988), Sex-related wage differentials and women's interrupted labor careers: The chicken or the egg, Journal of Labor Economics 6, 277-301.

Häkkinen, I (1996), Working while enrolled in university: Does it pay? Labour Economics 13, 167-189.

Heckman, J and S Polachek (1974), Empirical evidence on the functional form of the earningsschooling relationship, Journal of the American Statistical Association 69, 350-354. 
Heckman, J, L Lochner and P Todd (2003), Fifty years of Mincer earnings regressions, NBER Working Paper 9732.

Heckman, J, L Lochner and P Todd (2005), Earnings functions, rates of return and treatment effects: The Mincer equation and beyond, NBER Working Paper No. 11544.

Hotz, J, L C Xu, M Tienda and A Ahituv (2002), Are there returns to the wages of young men from working while in school? Review of Economics and Statistics 84, 221-236.

Högkoleverket (1997), Tillträde till högre utbildning - en evighetsfråga, Högskoleverkets skriftserie 1997:13 S, Högskoleverket (National Agency for Higher Education).

Landell, E, O Gustafsson and D Grannas (2000), Utbildningens omvägar (Detours in Swedish education), ESO-report Ds 2000:58, Fritzes.

Le Grand, C, R Szulkin and M Tåhlin (2001), Lönestrukturens förändring i Sverige (Changes in the Swedish Wage Structure), in Välfärd och arbete i arbetslöshetens årtionde (SOU 2001:53), Fritzes.

Light, A (1995), The effects of interrupted schooling on wages, Journal of Human Resources 30, 472-502.

Light, A and M Ureta (1995), Early-career work experience and gender wage differentials, Journal of Labor Economics 13, 121-154.

Marcus, R (1984), Measuring the rate of return to interrupted schooling, Journal of Educational Statistics 9, 295-310.

Mincer, J (1974), Schooling, Experience and Earnings, Columbia University Press.

Mincer, J and S Polachek (1974), Family investments in human capital: Earnings of women, Journal of Political Economy 82, S76-S108.

Mincer, J and H Ofek (1982), Interrupted work careers: Depreciation and restoration of human capital, Journal of Human Resources 17, 3-24.

Monks, J (1997), The impact of college timing on earnings, Economics of Education Review 16, 419-423.

Nordström Skans, O and L Lindqvist (2005), Causal effects of subsidized career breaks, IFAU Working Paper 2005:17.

Nordström Skans, O, Edin P-A and B Holmlund (2006), Wage dispersion between and within plants: Sweden 1985-2000, manuscript IFAU.

Smith, J and R Naylor (2001), Determinants of degree performance in UK universities: A statistical analysis of the 1993 student cohort, Oxford Bulletin of Economics and Statistics 63, 29-60. 
Stafford, F and M Sundström (1996), Time out for childcare: Signalling and earnings rebound effects for men and women, Labour 10, 609-629.

Statistics Sweden (2002), Övergång gymnasieskola - högskola (The transition from upper secondary school to higher education), UF 36 SM 0201.

Statistics Sweden (2003), Universitet och högskolor. Genomströmning och resultat i högskolans grundutbildning t.o.m. 2001/02 (Higher education - throughput and result in undergraduate education up to 2001/02 inclusive), UF 20, SM032.

Statistics Sweden (2004), Övergång gymnasieskola - högskola (The transition from upper secondary school to higher education), UF 36 SM 0401.

Velfærdskommissionen (2005), Fremtidens velfæerd - vores valg. Report from the Danish welfare commission (http://www.velfaerd.dk). 


\section{Appendix}

Table A1. Descriptive statistics for cohorts born 1966-1972.

\begin{tabular}{|c|c|c|c|c|c|c|}
\hline & \multicolumn{3}{|c|}{ Men } & \multicolumn{3}{|c|}{ Women } \\
\hline & No gap & $1-2$ yrs gap & 3-4 yrs gap & No gap & $1-2$ yrs gap & 3-4 yrs gap \\
\hline Gap & 0.000 & 1.558 & 3.358 & 0.000 & 1.432 & 3.409 \\
\hline Estimated Gap & 0.071 & 1.659 & 3.341 & 0.084 & 1.458 & 3.327 \\
\hline Born in Nordic Countries & 0.006 & 0.005 & 0.008 & 0.007 & 0.006 & 0.007 \\
\hline Born Western Europe or North America & 0.005 & 0.004 & 0.003 & 0.005 & 0.004 & 0.003 \\
\hline Other Immigrants & 0.019 & 0.014 & 0.014 & 0.023 & 0.018 & 0.016 \\
\hline 2-year High School & 0.047 & 0.043 & 0.121 & 0.059 & 0.084 & 0.200 \\
\hline GPA & 4.054 & 3.844 & 3.481 & 4.023 & 3.845 & 3.581 \\
\hline No father in the data & 0.072 & 0.076 & 0.080 & 0.072 & 0.079 & 0.083 \\
\hline No mother in the data & 0.030 & 0.029 & 0.029 & 0.030 & 0.031 & 0.029 \\
\hline \multicolumn{7}{|l|}{ Father's Education } \\
\hline Less than High School & 0.248 & 0.235 & 0.275 & 0.248 & 0.248 & 0.278 \\
\hline High School & 0.183 & 0.187 & 0.238 & 0.230 & 0.224 & 0.289 \\
\hline University & 0.464 & 0.466 & 0.368 & 0.417 & 0.414 & 0.314 \\
\hline Missing & 0.106 & 0.111 & 0.119 & 0.105 & 0.114 & 0.119 \\
\hline \multicolumn{7}{|l|}{ Father's Socioeconomic Class } \\
\hline Nonprofessional Manufacturing & 0.035 & 0.031 & 0.038 & 0.041 & 0.036 & 0.046 \\
\hline Professional Manufacturing & 0.068 & 0.059 & 0.078 & 0.081 & 0.078 & 0.098 \\
\hline Service & 0.032 & 0.033 & 0.044 & 0.040 & 0.042 & 0.052 \\
\hline Low-level White Collar & 0.065 & 0.072 & 0.077 & 0.074 & 0.072 & 0.081 \\
\hline Intermediate-level White Collar & 0.212 & 0.196 & 0.221 & 0.205 & 0.206 & 0.210 \\
\hline Higher-level White Collar & 0.274 & 0.272 & 0.224 & 0.247 & 0.238 & 0.182 \\
\hline Leading position & 0.143 & 0.162 & 0.134 & 0.140 & 0.145 & 0.135 \\
\hline Farmer & 0.020 & 0.017 & 0.018 & 0.025 & 0.026 & 0.030 \\
\hline Unclassified Employee & 0.026 & 0.030 & 0.031 & 0.027 & 0.029 & 0.028 \\
\hline Information missing & 0.126 & 0.128 & 0.135 & 0.120 & 0.129 & 0.138 \\
\hline Else & 0.008 & 0.006 & 0.009 & 0.007 & 0.008 & 0.008 \\
\hline \multicolumn{7}{|l|}{ Mother's Education } \\
\hline Less than High School & 0.255 & 0.254 & 0.284 & 0.265 & 0.263 & 0.297 \\
\hline High School & 0.211 & 0.208 & 0.257 & 0.235 & 0.223 & 0.281 \\
\hline University & 0.485 & 0.488 & 0.406 & 0.452 & 0.462 & 0.372 \\
\hline Missing & 0.049 & 0.050 & 0.053 & 0.048 & 0.052 & 0.049 \\
\hline \multicolumn{7}{|l|}{ Mother's Socioeconomic Class } \\
\hline Nonprofessional Manufacturing & 0.015 & 0.011 & 0.015 & 0.018 & 0.012 & 0.018 \\
\hline Professional Manufacturing & 0.006 & 0.006 & 0.006 & 0.007 & 0.006 & 0.009 \\
\hline Service & 0.149 & 0.150 & 0.197 & 0.170 & 0.170 & 0.213 \\
\hline Low-level White Collar & 0.189 & 0.187 & 0.200 & 0.186 & 0.191 & 0.207 \\
\hline Intermediate-level White Collar & 0.284 & 0.292 & 0.284 & 0.278 & 0.292 & 0.270 \\
\hline Higher-level White Collar & 0.185 & 0.185 & 0.123 & 0.172 & 0.160 & 0.112 \\
\hline Leading position & 0.045 & 0.045 & 0.045 & 0.041 & 0.045 & 0.040 \\
\hline Farmer & 0.011 & 0.008 & 0.008 & 0.012 & 0.012 & 0.013 \\
\hline Unclassified Employee & 0.021 & 0.025 & 0.028 & 0.022 & 0.024 & 0.022 \\
\hline Information missing & 0.096 & 0.093 & 0.094 & 0.094 & 0.088 & 0.095 \\
\hline Else & 0.004 & 0.004 & 0.004 & 0.005 & 0.003 & 0.005 \\
\hline Employed at age 30 & 0.952 & 0.944 & 0.936 & 0.931 & 0.917 & 0.900 \\
\hline Number of observations & 6892 & 15930 & 10574 & 10126 & 20663 & 9373 \\
\hline
\end{tabular}


Table A2. Experience measures at age 35 for cohorts born 1966-67.

\begin{tabular}{l|cccc|cccc}
\hline & \multicolumn{4}{|c|}{ Years } & \multicolumn{4}{c}{ Fraction of time } \\
& Mean & Sd & Min & Max & Mean & Sd & Min & Max \\
\hline Gap & 1.72 & 1.27 & 0 & 4 & -- & -- & -- & -- \\
Duration & 4.92 & 1.20 & 3 & 7 & -- & -- & -- & -- \\
\hline Experience & & & & & & & & \\
Before & 0.69 & 0.89 & 0 & 4 & 0.32 & 0.31 & 0 & 1 \\
During & 1.87 & 1.50 & 0 & 7 & 0.38 & 0.28 & 0 & 1 \\
After & 8.31 & 2.31 & 0 & 14 & 0.89 & 0.18 & 0 & 1 \\
Total & 10.87 & 2.43 & 0 & 15 & 0.72 & 0.16 & 0 & 1 \\
\hline
\end{tabular}

Notes: Work experience is for ages 20 to 34. Gaps between high school and university are bounded between 0 and 4 and Duration of university studies are bounded between 3 and 7 . Before (during, after) refers to before (during, after) university studies. Fraction of time is the number of years of experience during an interval (before, during or after) divided by the number of years in the interval.

Table A3. Sensitivity checks - variations in included covariates at age 30 and 35.

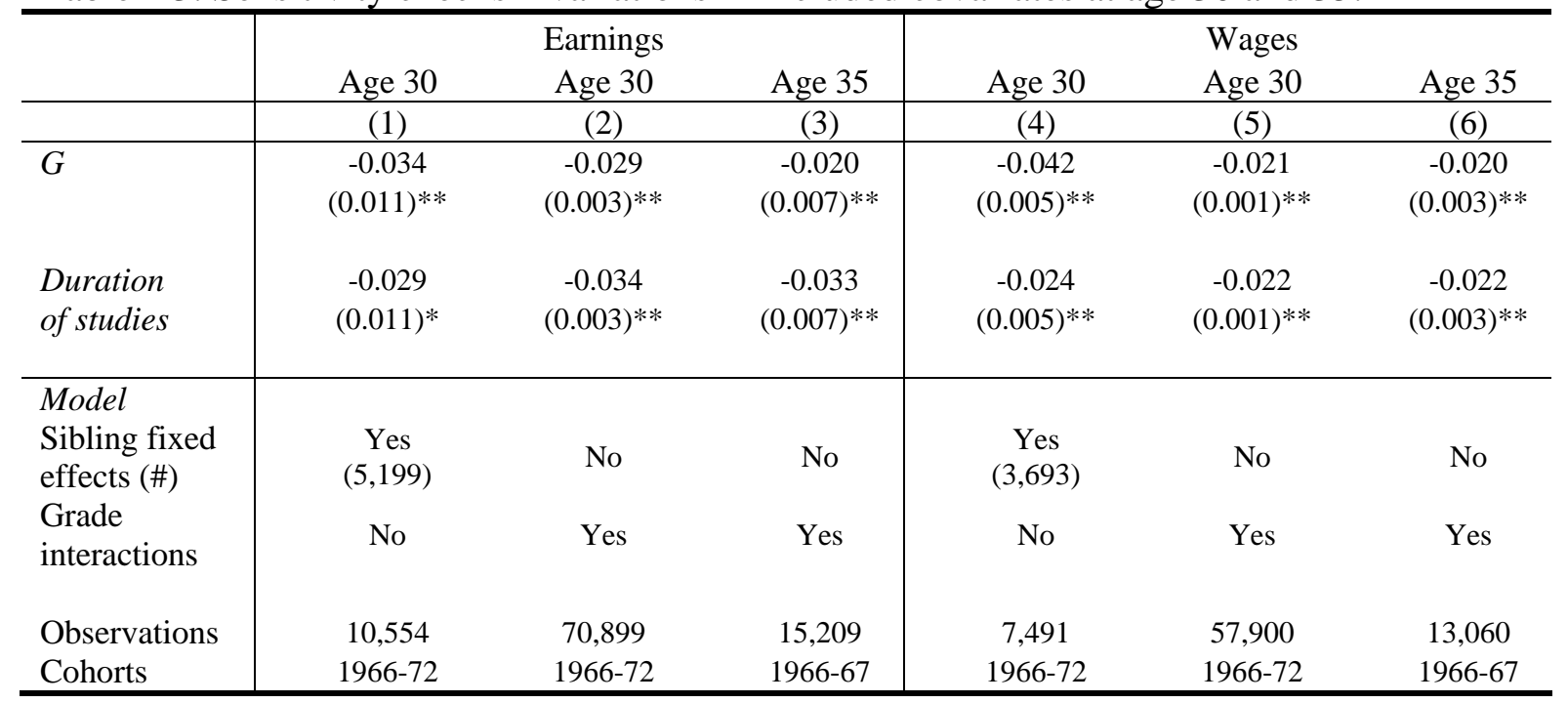

Note: Sibling fixed effects are defined from having the same biological mother, the sibling fixed effects regressions only include individuals with a sibling in the sample. Sibling model also controls for educational fields. Grade interactions model interacts high school grades with both the field of the high school education (60 categories) and the field of the university education (450 categories). Grade interaction model also controls for parent characteristics, county and immigration status. All regressions control for gender and year of birth. Robust standard errors in the parentheses. * significant at $5 \%$; ${ }^{* *}$ significant at $1 \%$. 
Figure A1. Description of the structure of the data.

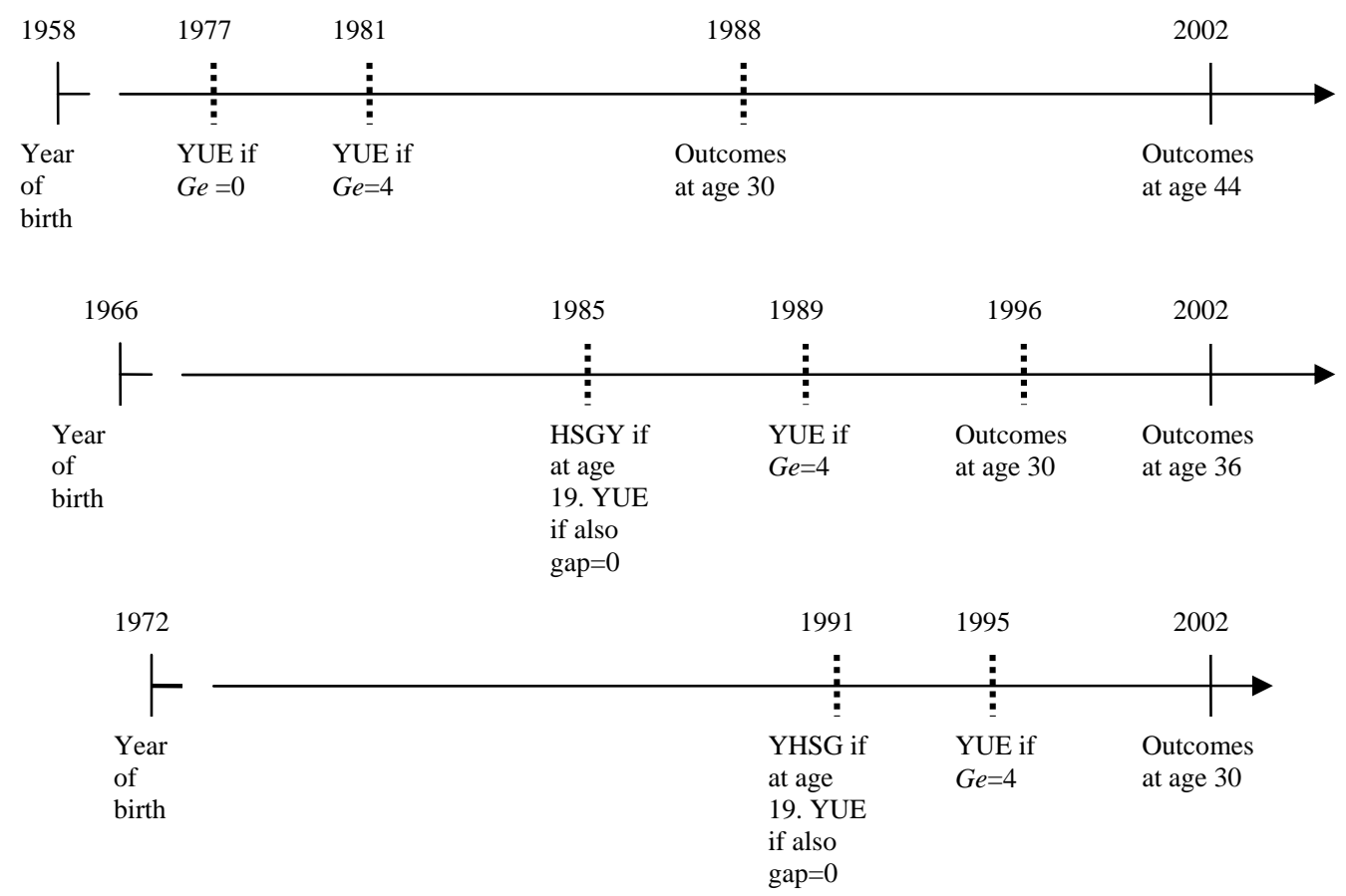

Figure A2. Estimated returns to gap years, by age and cohort.

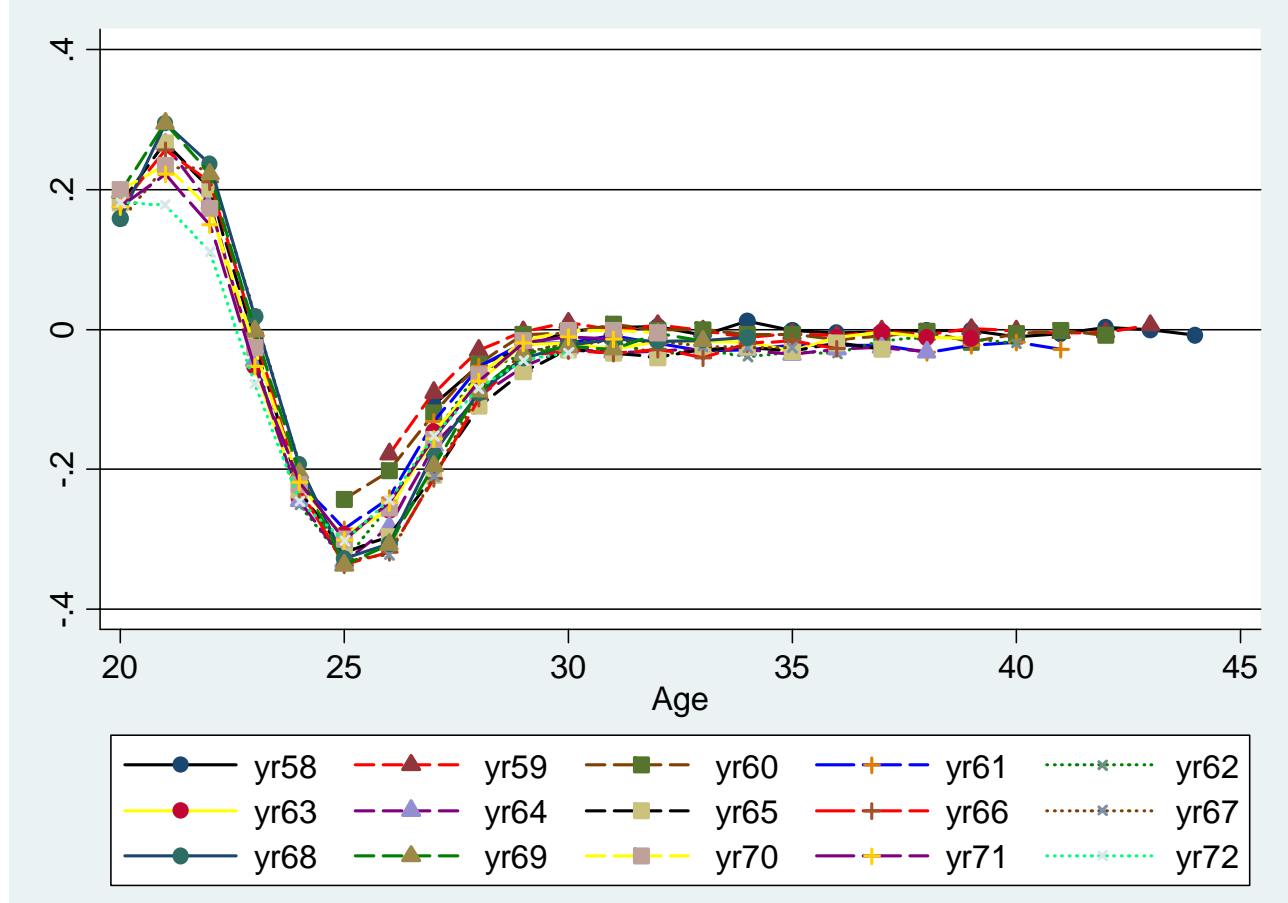

Note: The figure shows the age pattern of gap estimates based on regressions with log annual earnings as dependent variable. Data for men and women are pooled. 
WORKING PAPERS*

Editor: Nils Gottfries

2005:10 Annika Alexius and Erik Post, Exchange Rates and Asymmetric Shocks in Small Open Economies. 31 pp.

2005:11 Martin Ågren, Myopic Loss Aversion, the Equity Premium Puzzle, and GARCH. 34 pp.

2005:12 Pär Holmberg, Numerical Calculation of an Asymmetric Supply Function Equilibrium with Capacity Constraints. 18 pp.

2005:13 Jovan Zamac, Winners and Losers from a Demographic Shock under Different Intergenerational Transfer Schemes. 44 pp.

2005:14 Peter Welz and Pär Österholm, Interest Rate Smoothing versus Serially Correlated Errors in Taylor Rules: Testing the Tests. 29 pp.

2005:15 Helge Bennmarker, Kenneth Carling and Bertil Holmlund, Do Benefit Hikes Damage Job Finding? Evidence from Swedish Unemployment Insurance Reforms. 37 pp.

2005:16 Pär Holmberg, Asymmetric Supply Function Equilibrium with Constant Marginal Costs. 27 pp.

2005:17 Pär Holmberg: Comparing Supply Function Equilibria of Pay-as-Bid and Uniform-Price Auctions. 25 pp.

2005:18 Anders Forslund, Nils Gottfries and Andreas Westermark: Real and Nominal Wage Adjustment in Open Economies. 49 pp.

2005:19 Lennart Berg and Tommy Berger, The Q Theory and the Swedish Housing Market - An Empirical Test. 16 pp.

2005:20 Matz Dahlberg and Magnus Gustavsson, Inequality and Crime: Separating the Effects of Permanent and Transitory Income. 27 pp.

2005:21 Jenny Nykvist, Entrepreneurship and Liquidity Constraints: Evidence from Sweden. 29 pp.

2005:22 Per Engström, Bertil Holmlund and Jenny Nykvist: Worker Absenteeism in Search Equilibrium. 35pp.

2005:23 Peter Hästö and Pär Holmberg, Some inequalities related to the analysis of electricity auctions. 7pp.

2006:1 Jie Chen, The Dynamics of Housing Allowance Claims in Sweden: A discrete-time hazard analysis. 37pp.

\footnotetext{
* A list of papers in this series from earlier years will be sent on request by the department.
} 
2006:2 Fredrik Johansson and Anders Klevmarken: Explaining the size and nature of response in a survey on health status and economic standard. 25pp.

2006:3 Magnus Gustavsson and Henrik Jordahl, Inequality and Trust: Some Inequalities are More Harmful than Others. 29pp.

2006:4 N. Anders Klevmarken, The Distribution of Wealth in Sweden: Trends and Driving factors. 20pp.

2006:5 Erica Lindahl and Andreas Westermark: Soft Budget Constraints as a Risk Sharing Arrangement in an Economic Federation. 22pp.

2006:6 Jonas Björnerstedt and Andreas Westermark: Bargaining and Strategic Discrimination. 36pp.

2006:7 Mikael Carlsson, Stefan Eriksson and Nils Gottfries: Testing Theories of Job Creation: Does Supply Create Its Own Demand? 23pp.

2006:8 Annika Alexius and Erik Post, Cointegration and the stabilizing role of exchange rates. 33pp.

2006:9 David Kjellberg, Measuring Expectations. 46pp.

2006:10 Nikolay Angelov, Modellig firm mergers as a roommate problem. 21pp.

2006:11 Nikolay Angelov, Structural breaks in iron-ore prices: The impact of the 1973 oil crisis. 41pp.

2006:12 Per Engström and Bertil Holmlund, Tax Evasion and Self-Employment in a High-Tax Country: Evidence from Sweden. 16pp.

2006:13 Matias Eklöf and Daniel Hallberg, Estimating retirement behavior with special early retirement offers. 38pp.

2006:14 Daniel Hallberg, Cross-national differences in income poverty among Europe's 50+. 24pp.

2006:15 Magnus Gustavsson and Pär Österholm, Does Unemployment Hysteresis Equal Employment Hysteresis? 27pp.

2006:16 Jie Chen, Housing Wealth and Aggregate Consumption in Sweden. 52pp.

2006:17 Bertil Holmlund, Quian Liu and Oskar Nordström Skans, Mind the Gap? Estimating the Effects of Postponing Higher Education. 33pp.

See also working papers published by the Office of Labour Market Policy Evaluation http://www.ifau.se/ 